\title{
IMPACT OF SOLID WASTE DUMP-SITES ON GROUNDWATER QUALITY IN BENIN CITY, NIGERIA
}

\author{
${ }^{* 1,2,3}$ Sam-Uroupa, R. E. and ${ }^{3}$ Ogbeibu, E. A.
}

\author{
${ }^{*}$ Edo State Ministry of Environment and Sustainability, Benin City, Nigeria \\ ${ }^{2}$ Edo State Oil and Gas Producing Areas Dev. Commission, Benin City, Nigeria \\ ${ }^{3}$ Department of Animal and Environmental Biology, Faculty of Life Sciences, University of Benin, Benin City, Nigeria \\ *Email: ewerericher@yahoo.com
}

\begin{abstract}
$\mathrm{M}$

unicipal waste dumpsites contain pollutants which are either water-solution or are capable of being moved along the path of water during percolation through the soil to groundwater. This study was therefore carried out to investigate the impact of solid waste dump-sites in Benin City on the receiving groundwater quality. Four stations were chosen for this study, with each station located within one Local Government Area. These stations were dump-sites at Ikhueniro (station 1), Costain (station 2) and Ugbioyoko (station 3). Omaghe (station 4) was used as the control station without waste dumpsite. Soil samples were collected at three distances from the dump-sites of $0-50 \mathrm{~m}, 50-100 \mathrm{~m},>100 \mathrm{~m}$ at $0-30 \mathrm{~cm}$ depth of top soil and analyzed while the boreholes used were within 120m radius from the dump-sites. This investigation spanned from July 2011 to December 2011. Results showed that water samples were found to be enriched with heavy metals (Fe, Mn, Zn, $\mathrm{Cu}, \mathrm{Cr}, \mathrm{Pb}, \mathrm{Ni}$ and $\mathrm{V}$ ) more than the control water sample; these were however within WHO and FMEnv. regulatory limits for drinking water. The mean $\mathrm{pH}$ values of the sampled water fluctuated between 4.50 and 5.57 and were not within the WHO and FMEnv. regulatory limits of 6.5 to $8.5 \mathrm{set}$ for drinking water. ANOVA revealed a highly significant difference $(\mathrm{p}<0.01$ ) between the means of the following water parameters; $\mathrm{Ca}, \mathrm{Na}, \mathrm{K}, \mathrm{Mg}$, electric conductivity, Salinity, $\mathrm{HCO}_{3}$, and total soluble solids. The Kruskal-Wallis Test revealed that aerobic bacterial count was significant $(\mathrm{p}<0.05)$ with the highest mean value in station $1\left(17.17 \mathrm{x} 10^{2} \mathrm{cfu} / \mathrm{ml}\right)$ and lowest mean value in station $4\left(6.00 \times 10^{2} \mathrm{cfu} / \mathrm{ml}\right)$. Seasonal pattern of variations was observed for water samples examined.
\end{abstract}

Keywords: Benin City, dump sites, Ikhueniro, water quality, municipal waste

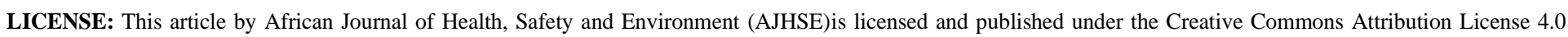
International License, which permits unrestricted use, distribution, and reproduction in any medium, provided this article is duly cited.

COPYRIGHT: The Author(s) completely retain the copyright of this published article.

OPEN ACCESS: The Author(s) approves that this article remains permanently online in the open access (OA) mode.

QA: This Article is published in line with "COPE (Committee on Publication Ethics) and PIE (Publication Integrity \& Ethics)". 


\section{INTRODUCTION}

The occurrence of wastes is almost an unavoidable one; it results from an activity which has no immediate economic demand and which must be disposed of (NISP, 2003). These types of wastes include predominantly domestic and commercial wastes collected by municipality within a given area (Bocco and Silke, 2001).

The production of waste by man is inevitable (Ogbeibu et al., 2013). Mankind is producing more refuse than ever before, creating problems for the environment. The growth in population coupled with increasing industrialization and indiscriminate waste disposal has led to huge volume of waste found in our environments today. Wastes and methods of getting rid of them cause a lot of problems in our environment and surroundings especially when they are not properly disposed. Often, the way people dispose of their waste is to simply drop it in some place. Open, unregulated dumps are still the method of waste disposal in most developing countries. The giant third world mega cities have enormous garbage problems. Waste cause air and water pollution. One of the severe problems associated with the open dumps is infiltration of leachate into the surrounding environment and subsequent contamination of the water. It is essential to protect ground and surface waters from contamination due to leachate percolation in and around the dump-sites. Leaching is the process by which nutrient chemicals or contaminants are dissolved and carried away by water or are moved into a lower layer of soil. The contaminated liquid formed from the infiltration of rain through the soil covering is called leachate. As the water seeps through the waste, water soluble chemicals may be picked up and carried along. This leachate then follows the normal hydrological flow and may enter the groundwater system (Ogbeibu et al., 2013).

Water is important to life. Water on the earth can be said to be enormous in quantity when it is considered that more than two-thirds of the earth surface is covered by water (Abdulaziz, 2003). Dauda (1993) observed that as surface water becomes increasingly polluted, people turn to groundwater for alternative supplies. Therefore, the development and efficient management of groundwater resources is of particular concern. The generation of solid wastes from households, industries, markets, abattoirs and shops result in the improving standard of living of the inhabitants. These solid wastes can as well contaminate groundwater. These leachates consist largely of solids, microbial organisms and in some situations, chemicals and shallow wells are more dangerously polluted. Groundwater became a major source of water supply in Benin City, due to inadequate water supply for the rapidly growing population, industrial and urban development. It has now become the predominant source of water either directly or indirectly through mechanically drilled wells generally referred to as bore-holes.

Therefore, the impact of waste dump-sites on the quality of groundwater becomes an important issue to consider, as it will be of great importance to individuals, especially the inhabitants of the area, Edo State Ministry of Environment and Public Utilities, Edo State Waste Management Board, Scientific Officers, Environmental Health Officers and Association of Accredited Waste Managers, Edo State Branch who would know the effect of their activities on the quality of groundwater, soil, environment and health. The outcome of this research could be beneficial to Local, State and Federal Governments as it will be useful in policy formulation, implementation, monitoring and evaluation, especially on issues relating to the environment, creation of waste dump-sites, water and sanitation management.

Groundwater plays a crucial role as a reservoir of freshwater which is required for portable water as well as irrigation water for agriculture. UNEP (2002) stated that "of the entire freshwater resource in the world, an estimated volume of 8 million $\mathrm{km}^{3}$ (30.8\%) are present as groundwater. Furthermore, UNEP (2002) also reported that the share groundwater has of the easily accessible freshwater is estimated to be even more than $90 \%$. 
During the last decade, Nigeria and Edo State in particular, has experienced acute water shortage as a result of rapid industrialization, urban development and poor management of the Edo State Urban Water Board and man-made environmental hazards. The goal of all countries is to increase economic production as it is generally thought that this will result in a better life for the citizens. In as much as the population of the country is growing, it is likely that the total use of water will increase. Run-offs from the scarce rainfall of the region are being charged with ever increasing loads of organic and mineral impurities that naturally recharge the aquifers. Therefore, an assessment of the impact of municipal waste on the receiving ground water would provide information necessary to help policy makers in strategizing on adequate measure or mechanisms to improve conditions already employed during waste disposal at the various sites as well as management of operations at the sites.

\section{MATERIALS AND METHODS \\ THE STUDY AREA}

The study was conducted in Benin metropolis, consisting of five Local Government Areas (LGA) including Oredo, Egor, Ikpoba-Okha, Ovia North-East and Uhunmwonde LGAs respectively. Benin City is the capital of Edo State, Nigeria (latitudes $6^{\circ} 16^{\prime} \mathrm{N}$ to $6^{\circ} 33^{\prime} \mathrm{N}$ and longitudes $5^{\circ} 31^{\prime} \mathrm{E}$ to $5^{\circ} 45^{\prime} \mathrm{E}$ (Figure 1 ). The areas of study were 3 major municipal solid waste dump-sites, namely Ikhueniro $\left(06^{\circ} 19^{\prime} 39.3^{\prime \prime N a n d} 005^{\circ} 44^{\prime} 45.9^{\prime \prime} \mathrm{E}\right.$ (elevation 88 $\mathrm{m})$; Costain $\left(06^{\circ} 20^{\prime} 50.0^{\prime \prime} \mathrm{N}\right.$ and $005^{\circ} 38^{\prime} 16.4^{\prime \prime} \mathrm{E}$ (elevation $\left.76 \mathrm{~m}\right)$; and Ugbiyoko $\left(\left(06^{\circ} 17^{\prime} 39.28^{\prime \prime} \mathrm{N}\right.\right.$ and $005^{\circ} 32^{\prime}$ 45.78"E (elevation 66m). Omaghe along Sapele Road (06 18' 40.6"N and 005 38' 13.8"E with elevation of 88m) was selected as the control sites since within the area there were no evidence of municipal solid waste disposal centres (Figure 2).

Four stations were chosen for this study from four different Local Government Areas with each station at one Local Government Area. The stations understudy were Ikhueniro dump-site, the dump-site at Costain, dump-site at Ugbiyoko and Omaghe, which was used as the control station was void of waste dump-site. 


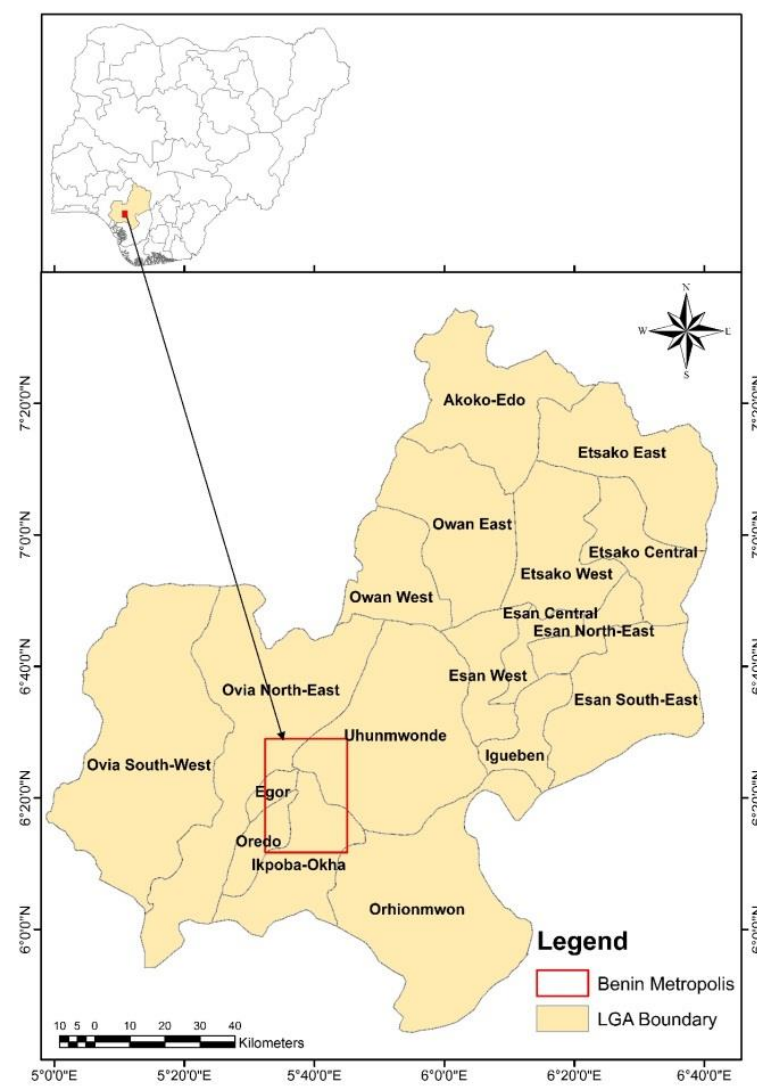

Figure 1: Administrative map of Edo State showing the limit of Benin Metropolis

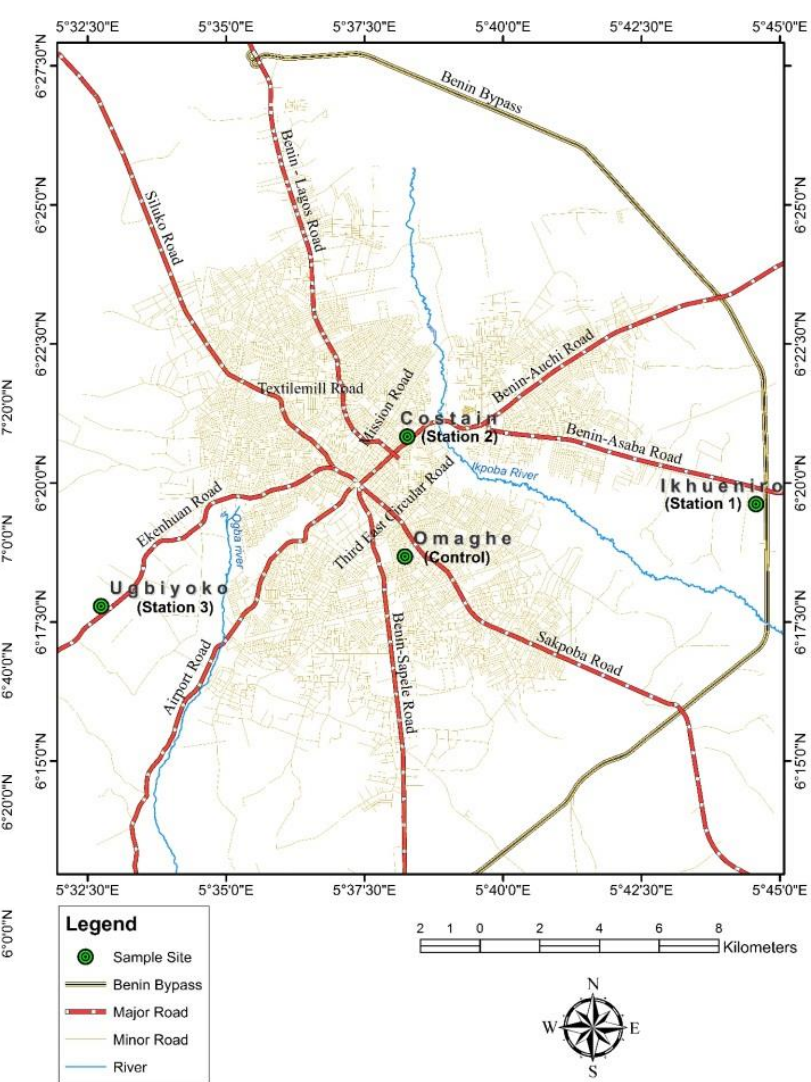

Figure 2: Map of Benin Metropolis showing the Sample Sites

\section{DESCRIPTION OF THE STUDY STATIONS}

Four stations were chosen for this study from four different Local Government Areas with each station at one Local Government Area. The stations understudy were Ikhueniro dump-site, the dump-site at Costain, dump-site at Ugbiyoko and Omaghe, which was used as the control station was void of waste dump-site.

\section{Station 1 (Ikhueniro Waste Dump-site)}

The Ikhueniro dump-site is an approved waste dump-site by the Edo State Government and managed by Edo State Waste Management Board. It is located along the Benin-Lagos bypass in Uhunmwonde Local Government Area of Edo State. It was an excavated site/burrow pit which was later converted into waste dump-site and has been in use for over 20years. Domestic, market, agricultural, hospital and industrial wastes, sewage and sludge including construction wastes are the commonest kind of waste found in this government approved dump-site. Quite often, wastes are spread across more than $90 \%$ of the land mass especially during the raining season when the vehicles have no access to the inner part of the dump-site as a result of poor management, thereby leading to indiscriminate dumping by waste managers/trucks. Once a while, the waste dump-site receives attention by a bail loader coming around to push the overflowing waste into the pit. Close to this dump-site are residential homes, pure water factory, commercial buildings and farmlands. This dump-site spans over 150m. A residential borehole located at a distance $>100 \mathrm{~m}$ from this dump-site was sampled for this research work. Soil samples were taken from around this vicinity at $0-50 \mathrm{~m}, 50-100 \mathrm{~m}$ and $>100 \mathrm{~m}$ distances from the dump-sites at a depth of $0-30 \mathrm{~cm}$. 


\section{Station 2 (Costain Waste Dump-site)}

The station at Costain is an illegal waste dump-site located in Oredo Local Government Area of Edo State. This dump-site which was formerly a monument to the Bini's (a moat), has been illegally patronized by waste managers, private companies and individuals for over 20years in dumping of various kinds of wastes. Domestic, market, agricultural, industrial, hospital wastes including sewage and sludge are the types of solid waste found in this dump-site. Residential homes, commercial buildings, factories with high population of people live in this area. This dump-site spans over $110 \mathrm{~m}$. A residential borehole located at a distance $<60 \mathrm{~m}$ from this dump-site was sampled for this research work. Soil samples were taken from around this vicinity at 0-50 m, 50-100 m and $>100 \mathrm{~m}$ distances from the dump-sites at a depth of 0-30 cm.

\section{Station 3 (The Waste Dump-site at Ugbiyoko)}

The Dump-site at Ugbiyoko is also an illegal waste dump-site located in Egor Local Government Area of Edo State. This area which was formerly a moat i.e. a monument to the Binis, has over the years be turned into a waste dump-site. This illegal dump-site has been in use for over 10 years. The common types of waste found in the dump-site are domestic, market, agricultural waste. Also, this waste dump-site is very close to farms, residential homes and a market. This dump-site spans over $65 \mathrm{~m}$. A community borehole located at a distance $<50 \mathrm{~m}$ from this dump-site was sampled for this research work. Soil samples were taken from around this vicinity at 0-50 m, 50-100 $\mathrm{m}$ and $>100 \mathrm{~m}$ distances from the dump-sites at a depth of 0-30 cm.

\section{Station 4 (Omaghe - The Control Station)}

Omaghe is a settlement located in Ikpoba-Okha Local Government Area of Edo State. This station is void of any waste dump site. This station is a highly populated residential area and it is therefore used as the control to this study. The distance of the control station from any of the waste dump-sites mentioned above is $>1 \mathrm{~km}$. Soil samples were taken at $0-50 \mathrm{~m}, 50-100 \mathrm{~m}$ and $>100 \mathrm{~m}$ distances from the borehole at a depth of $0-30 \mathrm{~cm}$.

\section{Sampling periodicity and procedure}

Water samples were taken from boreholes located in the dump-site stations. The study focused on water bearing formations generally less than $150 \mathrm{ft}$ from the ground surface, since it is the aquifer that is vulnerable to contamination. The boreholes used were within $120 \mathrm{~m}$ radius from the dump-sites. Water sample from a borehole at Omaghe which is the control station was also collected.

Water samples were collected on a monthly interval from the four stations for a period of six months spreading through July 2011 - December 2011. All samples were collected between the hours of 7a.m and 12noon. Sampling equipment were properly cleaned and calibrated before field work. The sample containers were washed and rinsed thoroughly with distilled water and subsequently soaked in dilute nitric acid. They were oven dried at $70{ }^{\circ} \mathrm{C}$ and finally rinsed with distilled water. After drying, all containers were rinsed with acetone and thoroughly with distilled water and, further rinsed with water collected at the respective sampling stations. Sampling equipment were properly cleaned and calibrated before field work. In situ parameters such as $\mathrm{pH}$, Temperature, Dissolved Oxygen (DO), Total Dissolved Solids (TDS), Electrical Conductivity (EC) and Turbidity were done with calibrated portable field meters. 


\section{Physicochemical Analysis of water Samples}

Following the methods of SSSA (1971); AOAC (1999); Zhang et al. (2010), physicochemical parameters analyzed includes; $\mathrm{pH}$, electrical conductivity, chlorine, Sulphate, Nitrate, Phosphate, Ammonium nitrogen, Calcium, Magnesium, Sodium, Potassium, Zinc, Copper, Chromium, Lead, Manganese, Iron, Nickel, moisture content, total organic carbon content and total nitrogen.

The water temperatures were measured using mercury-glass thermometer with $0^{\circ} \mathrm{C}$ to $100^{\circ} \mathrm{C}$ calibration. The thermometer was left in water media for about 2 minutes before the reading was taken. Turbidity was carried out with the aid of a turbidimeter. The turbidimeter was standardized by putting the 90 NTU cell in the sample compartment and adjusting the control knob to 90 NTU. This was later removed and the sample cell, containing $25 \mathrm{ml}$ of sample was put into the cell holder and the reading recorded.

The $\mathrm{pH}$ of each water sample was determined using the calorimetric method employing phenol red as indicator. In the laboratory, they were further confirmed using a Philip's pH meter. The electrical conductivity of the samples was determined using a $\mathrm{HACH}$ conductivity meter by dipping the conductivity probe into a beaker containing the sample and taking the reading from the meter. Water salinity was determined in the laboratory by the Anderson and Ingram's (1989) titrimetric method with an accuracy of $\pm 0.1 \%$.

Dissolved Oxygen was estimated using the winkler's method (Schwoerbel, 1972). Samples were collected in the field using $250 \mathrm{ml}$ DO glass bottles with glass stoppers. The bottles were filled and stoppered below the water surface in a clean plastic bucket to avoid air bubbles in the bottles. The samples were fixed in the field by adding $1 \mathrm{ml}$ of Winkler's solution A (Manganese Tetraoxosulphate (VI)), followed by $1 \mathrm{ml}$ of Winkler's solution B (Alkali-Iodide-Azide or Potassium Iodide) to each bottle. The stopper was carefully replaced, so as to avoid the inclusion of air bubbles and then shaken thoroughly by tilting the bottle to mix the fluid. The precipitate so formed by these additions was dissolved by adding $2 \mathrm{ml}$ of concentrated hydrogen tetraoxosulphate (VI) acid in the laboratory. From the resulting golden yellow solution, $100 \mathrm{ml}$ with $2-3$ drops of starch indicator was titrated against $0.025 \mathrm{M}$ sodium thiosulphate $\left(\mathrm{Na}_{2} \mathrm{~S}_{2} \mathrm{O}_{3}\right)$ solution. The end point was the complete disappearance of the initial blue-black colouration developed on addition of starch. The total volume of titre used in the determination is equivalent to the amount of dissolved oxygen in $\mathrm{mg} / \mathrm{l}$.

Magnesium content was determined titrimetrically using the EDTA method. In this procedure, calcium and magnesium were determined together before extrapolation to obtain magnesium. $50 \mathrm{ml}$ of sample was put in an Erlenmeyer flask and $3 \mathrm{ml}$ of ammoniacal buffer solution was added followed by 2 drops of the indicatorinhibitor solution. The titre 0.01 M EDTA solution was added to the sample until it changed from wine red colour to a sky-blue end point. The value of magnesium $\mathrm{K}$ was obtained by the following equation:

$$
\mathrm{K}=(\mathrm{a}-\mathrm{h}) 0.2432
$$

Where:

$$
\begin{aligned}
& \mathrm{K}=\text { value of magnesium in } \mathrm{mg} / \mathrm{l} \\
& \mathrm{a}=\text { titre volume for calcium and magnesium titration } \\
& \mathrm{h}=\text { titre volume for calcium titration only }
\end{aligned}
$$

For total Hydrocarbon, $50 \mathrm{ml}$ of the water sample was measured into $150 \mathrm{ml}$ separating funnel. $25 \mathrm{ml}$ of hexane was added and then, it was shaken for 2 minutes manually. The stopper was removed and allowed to settle for 20 minutes. The water layer was drained off and the hexane layer was collected and read at $460 \mathrm{~nm}$. The 
hexane was used as the blank. $1.18 \mathrm{ml}$ of Forcados was pipette; crude oil blended and made up to 1 litre with $\mathrm{n}-$ Hexane. From this, 0, 10, 20, 40, 60, 80, and 100 pm working standards were prepared.

THC was calculated therefore as:

$$
\mathrm{THC}(\mathrm{mg} / \mathrm{l})=\text { Instrument Reading } \times \text { Slope Reciprocal x } 0.5 \mathrm{mg} / \mathrm{l}
$$

Heavy metals were analyzed using the Atomic Absorption Spectrophotometer (AAS). Each metal has a hollowed cathode lamp for its determination. The water sample was sprayed through a nebulizer into an air-acetylene flame resonance line in element, which was generated in a hollow cathode lamp and was simultaneously passed through the flame. The absorbance of radiant energy by the element of interest was related to its concentration in the water sample by Beer - Lambert law (SSSA, 1971; AOAC, 1999).

\section{Identification of Soil Microorganisms}

Enumeration of bacterial and fungi counts were conducted according to methods prescribed by Cheesbrough (2001).

\section{Statistical analysis}

Besides the basic statistical measurements of central tendency and dispersion to characterize the stations in terms of the physico-chemical conditions, inter-station comparisons were carried out to test for significant differences in physico-chemical conditions and microbial assay using One-way Analysis of Variance (ANOVA) tests. Test of significance for soil and water microbial assay across the distance was carried out using non-parametric; Kruskal-Wallis $(\mathrm{H})$ test. If significant ' $\mathrm{H}$ ' values $(\mathrm{P}<0.05, \mathrm{P}<0.01, \mathrm{P}<0.001)$ were obtained, Duncan Multiple Range (DMR) tests were performed to determine the source of significant differences. The statistical packages used include SPSS (version 17.0) and Microsoft Excel 2010 statistical tool pack. Graphical presentations were also carried out using Microsoft excel.

\section{RESULTS AND DISCUSSION}

The problem and major environmental concerns associated with the dispersal of industrial and urban wastes generated by human activities is the contamination of the soil, controlled and uncontrolled disposal of wastes, accidental and process spillage, mining and smelting of metalliferous ores and sewage sludge application to agricultural soils are responsible for the migration of contaminants onto non-contaminated sites as dust or leachates and contribute towards contamination of our ecosystem (Ghosh and Singh, 2005). Generally, groundwater is believed to be the purest known because of the purification properties of the soil; however, it can also be contaminated. Groundwater is found to be contaminated due to improper construction, shallowness, animal wastes, proximity to toilet facilities, sewage, refuse dump sites, and various human activities around the well. Hence, this study is to find out the impact of waste dump-sites on our environment by assessing the status of the soil, the water quality from around the dump-sites and outside the dump-sites (control) area.

Tables 1 and 2 show the comparison of mean values for physical and chemical parameters of borehole water sampled across the four stations and across the months using one -way analysis of variance respectively (July 2011 to December 2011) in Benin Metropolis. 
The results of monthly variations in hydrogen ion concentration $(\mathrm{pH})$ of borehole water at the study stations were slightly acidic. The mean hydrogen ion concentration $(\mathrm{pH})$ was highest (5.57) in station 1 and lowest (4.50) in station 2 across the sampled stations. There was no clear pattern of seasonal variations in the $\mathrm{pH}$ values across the months except for the fact that, there was a steady increase in the mean values from the month of July to December. The month of December had the highest mean value (5.23) while that of July recorded the lowest mean value (4.80). The one-way analysis of variance was used to examine the difference in means. A highly significant difference was obtained $(\mathrm{P}<0.01)$ across the stations while there was no significant difference $(\mathrm{P}>0.05)$ across the months. A posteriori DMR test revealed that station 2 was the lowest while station 1 was highly significant from stations 3 and 4 which were not different from each other. Electrical conductivity is a measure of the total ionic composition of water and therefore its overall chemical richness. It is primarily determined in water by the presence and levels of concentration of sodium and magnesium ions and to some extent calcium ions. Their ions help buffer the effect of biocarbonate and carbonate ions, thus maintaining the pH (Raymont, 1983). The mean values of electrical conductivity was highest in station $2(494.17 \mu \mathrm{S} / \mathrm{cm})$ and lowest in station $4(252.00$ $\mu \mathrm{S} / \mathrm{cm})$ across the sampled stations. The mean values of electrical conductivity was highly significant $(\mathrm{P}<0.01)$ recording higher values in the test stations than the control station but falls within the desirable limit set by WHO standards. This report is similar with that of Ogbeibu et al. (2013) where groundwater samples away from the refuse dump-site had lower electrical conductivity. Across the study month, electrical conductivity mean values fluctuated slightly being highest in the month of December and lowest in the month of July. This fluctuation appears to be related to the rainfall pattern. High values recorded during the dry season and the dump-site stations can be attributed to concentration of ions by evaporation and increased mineralization of organic matters. The reverse is the case during rainy season which is due to dilution effect. This observation is similar to the findings of Egborge (1971), Onwudinjo (1990) and Omoigberale (2005) for water bodies.

The results of the analysis of the groundwater revealed that the in-situ mean values of groundwater temperature ranged from $26.48^{\circ} \mathrm{C}$ to $26.72^{\circ} \mathrm{C}$ which is similar to the study of Olobaniyi and Owoyemi (2004) and Ogbeibu et al. (2013) but was above the mean concentration $\left(23.16^{\circ} \mathrm{C}-23.52^{\circ} \mathrm{C}\right)$ recorded by Omoigberale et al. (2009) on Assessment of Groundwater Quality of Benin City, Edo State, Nigeria. It showed no significant difference between the test station and the control station but was within the FMEnv. regulatory limit of $30^{\circ} \mathrm{C}$. It recorded a highly significant difference ( $\mathrm{P}<0.01)$ across the months with a steady increase from July (lowest) to December 2011 (highest). Thus, it is expected that relatively higher water temperature should be obtained in the dry season than in the rainy season. Omoigberale (2005) and Ogbeibu et al. (2013) recorded such in their studies in Lagos harbor, Warri River, Osse River and groundwater in Ekurede-Urhobo, Warri respectively.

The $\mathrm{pH}$ mean values fluctuated between 4.50 and 5.57 and were not within the WHO and FMEnv regulatory unit of 6.5 to 8.5 set for drinking water. Similar results were obtained by Ogbeibu et al. (2013) when they worked on the effect of an open waste dump-site on its surrounding groundwater in Ekurede-Urhobo, Warri, Delta State, Nigeria. This is also in line with our value obtained for soil in the month of July, 2011 where the soils were found to be moderately acidic and, in pal with Omoigberale et al. (2009). It recorded a steady trend of increase across the study months with its lowest mean value (4.80) in the month of July and highest in the month of December (5.23). A similar trend of $\mathrm{pH}$ values being relatively lower in the rainy season than in the dry season was also reported by Awachie (1981), Omoigberale (2005) and Ogbeibu et al. (2013). The acidic nature of African rivers had earlier been recorded by various workers (Holden \& Green, 1960; Ajayi and Osibanjo, 1981; Fufeyin, 
1987; Ogbeibu and Victor, 1989). This indicated that the water is moderately acidic with little fluctuations in $\mathrm{pH}$ values recorded. The $\mathrm{pH}$ of waters usually determines the nature of carbon dioxide in water, free carbon dioxide is known to be present at lower $\mathrm{pH}$ ranges of 4.8-5.5, the carbonate and bicarbonates dominate at higher $\mathrm{pH}$ (Onwudinjo, 1990).

Determination of potassium was made at all stations across the months. It recorded the highest mean value $(20.42 \mathrm{mg} / \mathrm{l})$ in station 2 while station 1 had the lowest $(0.36 \mathrm{mg} / \mathrm{l})$. A highly significant difference $(\mathrm{P}<0.01)$ was observed in the mean values when tested with one-way analysis of variance. A posteriori DMR test revealed that station 2 was highly significantly different from other stations. Station 4 was higher than stations 1 and 3 which were not different from each other. Across the sampled months, December recorded the highest mean values $(11.10 \mathrm{mg} / \mathrm{l})$ while July recorded the lowest $(5.18 \mathrm{mg} / \mathrm{l})$. There was no significant difference $(\mathrm{P}>0.05)$ when tested with one-way analysis of variance.

The spatial and temporal variations in temperature and salinity of borehole water across the study stations and months are shown in Figures 1 and 2 respectively. The highest and lowest mean values were recorded in station $3\left(26.72^{\circ} \mathrm{C}\right)$ and station $4\left(26.48^{\circ} \mathrm{C}\right)$ for temperature and, station $2(0.21 \mathrm{~g} / \mathrm{l})$ and station $4(0.12 \mathrm{~g} / \mathrm{l})$ for salinity respectively. No significant difference $(\mathrm{P}>0.05)$ was obtained for temperature and a highly significant difference $(\mathrm{P}<0.01)$ was obtained for salinity when both were tested with one-way analysis of variance. $A$ posteriori DMR revealed that station 2 was highly significant from stations 1, 3 and 4 which were not different from each other. Salinity mean values showed a highly significant difference $(\mathrm{P}<0.01)$ between the test stations and the control station with dump-site stations recording higher values than the control station. This reveals that the dump-sites have an impact on the salinity of borehole water in its vicinity. The salinity fluctuates slightly across the study months recording its lowest value in the month of July and highest in the month of December with no significant difference $(\mathrm{P}>0.05)$. The values increased with dry season and can be attributed to the decomposition of litter and its mineralization around the dump-sites area, as well as the concentration of salts through evaporation. This was also reported by Omoigberale (2005) on the Assessment of Water Quality of River Osse using Physical Chemical and Biological Indicators. 


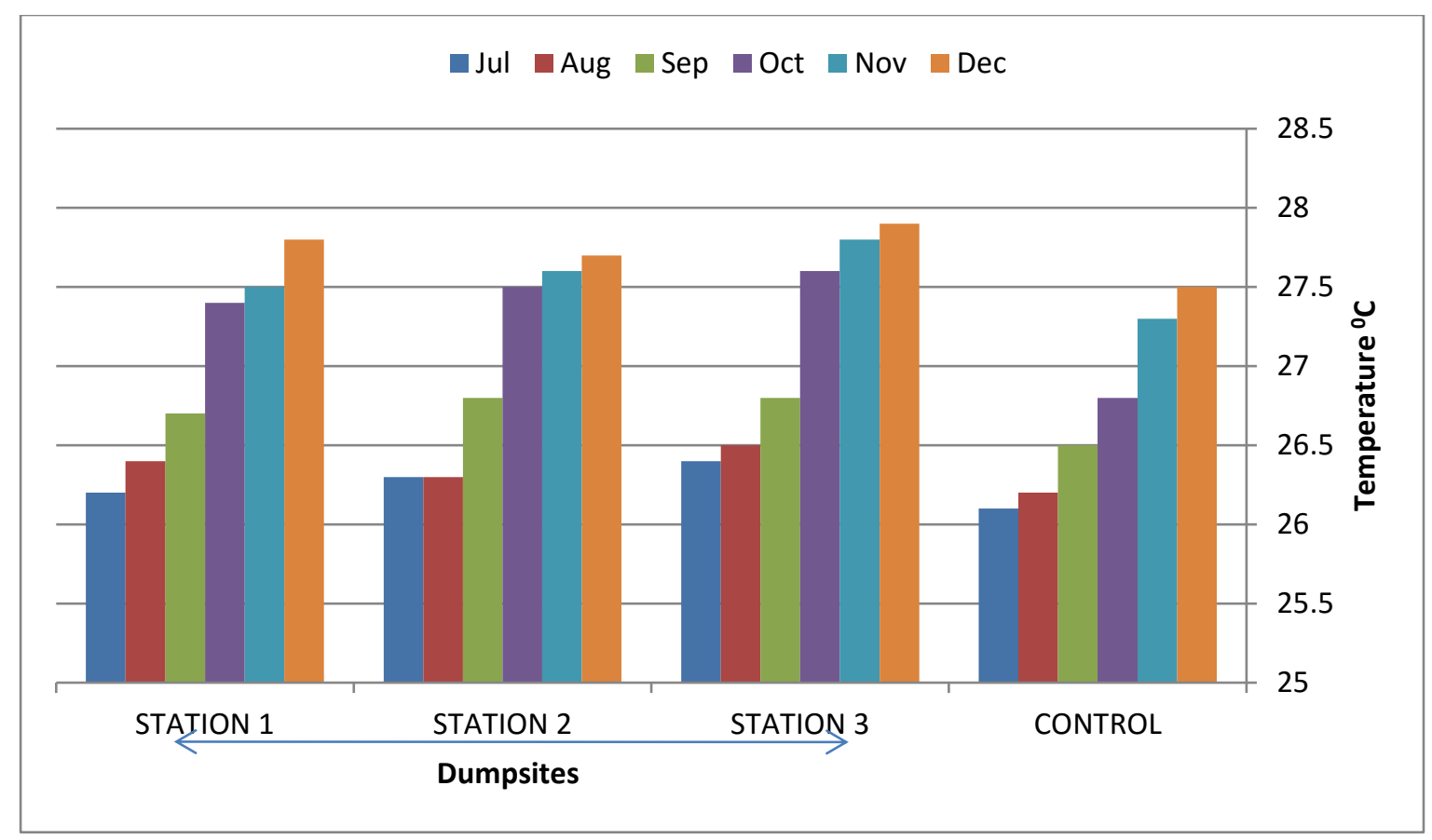

Figure 1: Spatial and temporal variations in temperature at the study stations

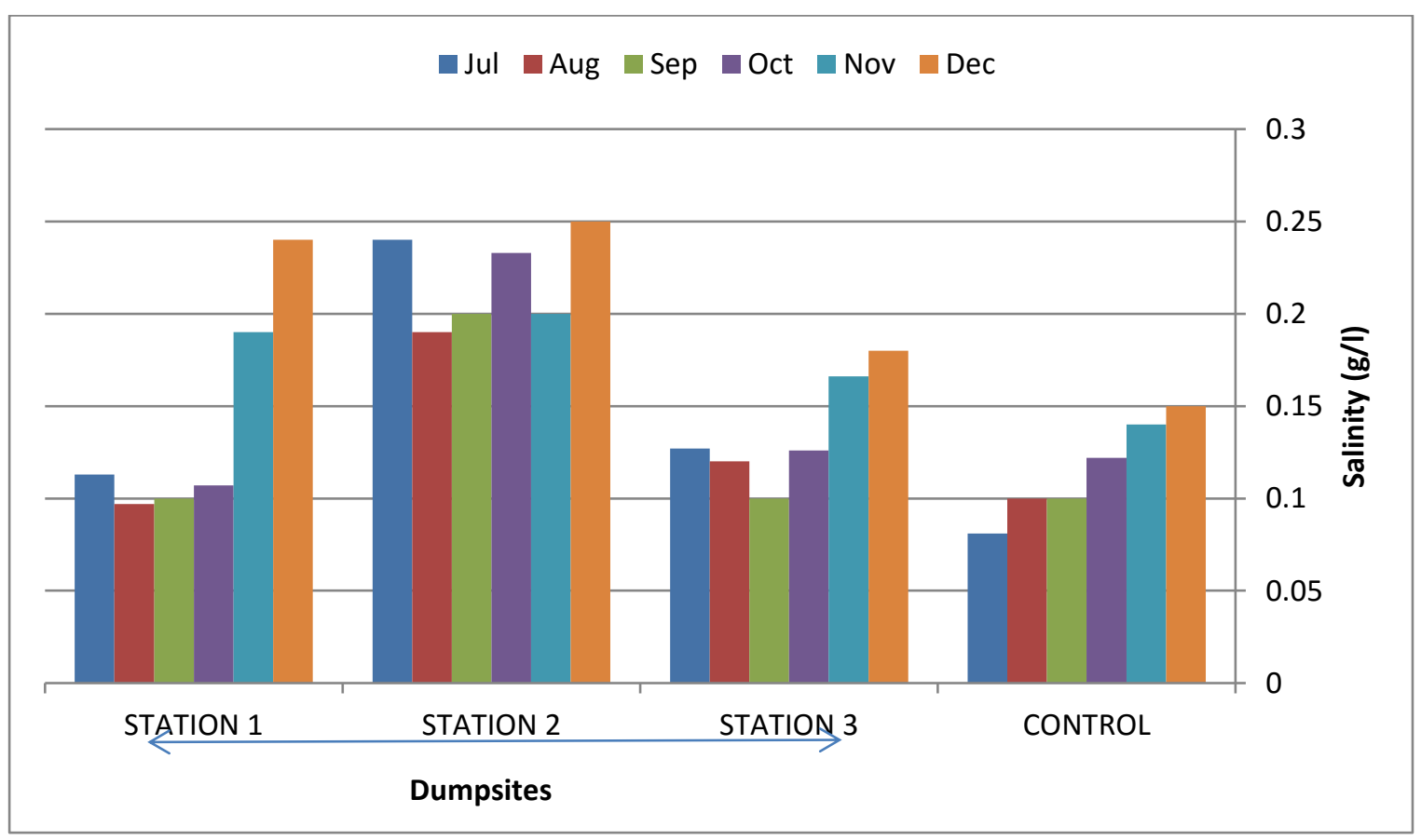

Figure 2: Spatial and temporal variations in salinity at the study stations

No taste, colour or odour was found in the borehole water samples collected except in station 2 for the month of July where a slightly tasty and nearly unnoticeable odour was observed.

Total suspended solids mean values recorded were minimal and was highly significant $(\mathrm{P}<0.01)$ across the study stations with station 3 recording no value at all. Station 2 and 4 mean values were higher than station 1, although the mean values recorded were within the prescribed limit of the FMEnv. The values of these parameters are very much similar to the values recorded in Ogbeibu et al. (2013) and very much lower than the values recorded in 
Shittu et al. (2008). Across the study months, there was no defined pattern of seasonal variations with no significant difference $(\mathrm{P}>0.05)$.

Total dissolved solids mean values were high during the dry season months and low in the rainy season months reflecting a seasonal pattern of variation although there was no significant difference $(\mathrm{P}>0.05)$. The influence of rains in diluting dissolved solids has been documented (Tenore, 1972; Beumer, 1980; Egborge and Okoi 1987 and Omoigberale, 2005). Across the study stations, it was highly significant $(\mathrm{P}<0.01)$ with the dumpsites stations having higher values than the control station. Although the values obtained were below the regulatory limits standards set by FMEnv. and WHO, there was an impact of waste dump-sites on the quality of water found. It was also observed that TDS values also increased with electrical conductivity which is supported by Mishra and Bhatt (2008); Omoigberale et al. (2009).

The dissolved oxygen was not significant $(\mathrm{P}>0.05)$ across the study stations. The FMEnv. and WHO limiting values were not crossed by any of the study stations with the exception of test station $3(5.13 \mathrm{mg} / \mathrm{l})$ which recorded a slight increase above the regulatory limit of 5.0 by FMEnv but within the permissible limit by WHO. The dissolved oxygen of the samples was fairly rich and within limits acceptable for domestic and agricultural activities. Across the study month, the results showed a highly significant difference $(\mathrm{P}<0.01)$ and seasonal trends with higher values observed in the dry season months and lower mean values in the rainy season months.

The biochemical oxygen demand test is useful for determining the degree of oxygen demand by biological organisms. It is often indicative of organically polluted water. The values obtained across the study stations including the control station were minimal (2.90 to 3.53) and within the regulatory limits set by WHO with a no significant difference $(\mathrm{P}>0.05)$. This is in line with the work of Omoigberale et al. (2009). It has been discovered that surface and shallow well waters with more coliform count had high BOD (Agbabiaka and Sule, 2010). This was not the case in this study as all the stations recorded low $\mathrm{BOD}_{5}$ values. Across the study months, it was significantly different $(\mathrm{P}<0.01)$ with a steady trend of seasonal monthly variation recording lower values in the rainy season while higher values were recorded in the dry season. The stations can be considered not to be organically polluted. Organic pollution occurs when the amount of organic matter present exceeds the threshold value and the oxygen content of the water cannot meet the need required for decomposition (Uhlmann, 1979). Organic pollution is usually due to sewage disposal in many developed countries and sewerage in developing countries. Therefore, the amount of organic waste present in the waste dump-site soil is not enough to cause pollution.

Chemical oxygen demand was highly significant $(\mathrm{P}<0.01)$ with higher values in the test stations while the control station recorded the lowest. Although, the values recorded did not exceed the regulatory set limit by FMEnv, it reflected that waste dump-sites have impacts on the quality of borehole water since the control value was much lower. It recorded a seasonal monthly variation with a highly significant difference $(\mathrm{P}<0.01)$. The seasonal trend recorded its higher values in the dry season months and its lower values in the rainy season months.

The values for hydrogen trioxocarbonate $\left(\mathrm{HCO}_{3}\right)$ showed a highly significant difference $(\mathrm{P}<0.01)$ between the tested and the control stations. Station $4(29.02 \mathrm{mg} / \mathrm{l})$ recorded the highest mean concentration while station $3(11.17 \mathrm{mg} / \mathrm{l})$ had the lowest. The dump-site stations recorded lower values than the control. The values obtained did not exceed the regulatory set limit by FMEnv. Across the months, it recorded its highest and lowest mean concentration in December $(22.88 \mathrm{mg} / \mathrm{l})$ and July $(12.20 \mathrm{mg} / \mathrm{l})$ respectively. This showed seasonal monthly variations with the rainy season months having lower values while the dry season months recorded higher values. 
Calcium, Sodium, Potassium and Magnesium of water across the stations were highly significant from each other $(\mathrm{P}<0.01)$ with station 2 recording the highest mean concentration. This finding could be due to the quantities of waste in station 2 and the closeness of the borehole to the waste dump-sites. The range of mean concentrations for $\mathrm{K}$ is $0.36 \mathrm{mg} / \mathrm{l}-20.42 \mathrm{mg} / \mathrm{l}$, Ca is $0.90 \mathrm{mg} / \mathrm{l}-17.39 \mathrm{mg} / \mathrm{l}, \mathrm{Mg}$ is $0.11 \mathrm{mg} / \mathrm{l}-2.09 \mathrm{mg} / \mathrm{land} \mathrm{Na}$ is $0.36 \mathrm{mg} / \mathrm{l}-20.22 \mathrm{mg} / \mathrm{l}$. The important cations (maximum values) were in the order $\mathrm{Na}>>\mathrm{K}>\mathrm{Ca}>\mathrm{Mg}$. The results obtained were similar to the common trend in African water bodies in which sodium is the most important cation (Talling and Rozoska, 1967; Imevbore, 1970). Higher levels of sodium over potassium are usually attributed to the retention of potassium by soil and living organisms (Visser, 1974).

It is known that calcium and magnesium along with their carbonates, sulphates and chlorides naturally confer temporary and permanent hardness. Water having 0-75mg $\mathrm{CaCO}^{3} \mathrm{l}^{-1}$ was describe as soft, $75-150 \mathrm{mg}$ $\mathrm{CaCO}^{3} \mathrm{l}^{-1}$ as hard water while samples having total hardness of over $300 \mathrm{mg} \mathrm{CaCO}_{3} \mathrm{~L}$ as hard according to Adeyeye and Abulude (2004). In line with this finding, the water under study can be classified as soft water. The present result corroborate with the results of Adeyeye and Abulude (2004) on "ground and water samples", Abulude et al., 2007 on "water samples in Akure", Alexander, 2008 on "the evaluation of groundwater quality in Mubi town", Adamawa State and Omoigberale et al. (2009) on Assessment of Groundwater Quality of Benin City, Edo State, Nigeria. Calcium and Magnesium mean values for all the study stations lie within FMEnv. and WHO regulatory set standards. The distribution of calcium and magnesium indicates that all values lie within the permissible limits of drinking water. The present of appreciable concentration of $\mathrm{Ca}$ and $\mathrm{Mg}$ were consistent with the level of hardness because higher values of $\mathrm{Ca}$ and $\mathrm{Mg}$ are consistent with total hardness. There was a steady trend of increase across the months from July to December with rainy season months having lower values while dry season months have higher values for calcium. This may be due to evaporation which led to concentration of calcium salts in the dry season (Holden and Green, 1960). One major source of calcium is the bedrock and weathering of calcium bearing rocks (Waite, 1984). Calcium is often the most common metallic ion in fresh surface water and among the most common in groundwater (Omoigberale, 2005). The values reported here in stations 1 and 3 may be an indication of the poor nature of the soil from where the borehole water arises. The reverse was the case for magnesium as there was no distinct pattern of variation although, rainy season months recorded higher values while dry season months had lower values.

Potassium and Sodium concentration were minimal except for station 2 which was highest as stated in the previous paragraph and control stations which followed. Sodium concentration values of more than $50 \mathrm{mg} / \mathrm{l}$ makes water unsuitable for drinking. Potassium and Sodium mean values obtained for all the study stations lay within FMEnv and WHO regulatory set standards for drinking water. Across the study months, there were no significant differences $(\mathrm{P}>0.05)$ but recorded their lowest mean values in the month of July and highest in the month of December. There were steady trend of increase across the months from July to December. The low concentration during July, August may be attributed to the dilution effect of rain water during the rainy season and concentrated value by evaporation during the dry season (December). Most of the minimal values recorded in the borehole water are in line with what was initially discovered in the soil sample analyzed.

Chloride was in the range of $21.46(\mathrm{mg} / \mathrm{l})$ to 45.07 (mg/l). The limit of chloride has been laid down primarily for taste consideration. A regulatory limit of $600 \mathrm{mg} / \mathrm{l}$ chloride has been recommended by FMEnv. and 200-600 WHO highest desirable and maximum permissible limits for drinking water. Water that contains less than $150 \mathrm{mg} / \mathrm{l}$ chloride is satisfactory for most purposes. A chloride content of more than $250 \mathrm{mg} / \mathrm{l}$ is generally 
objectionable for a municipal use and water containing more than $350 \mathrm{mg} / \mathrm{l}$ is objectionable for most irrigation and industrial uses (Omofonmwan and Eseigbe, 2009). Chloride can travel a great distance in groundwater (Hughes 2004). Chloride can get into groundwater from solid waste when it comes in contact with rain water and then gain entrance into the aquifer. Groundwater in Benin Metropolis varies considerably in chloride content. From available data obtained from the results of water analysis, some wells contain 1.64, 10.64, 17.73, 39.9, 43.10 and 56.21 which shows variation in the amount of chlorine in water in Benin Metropolis (Omofonmwan and Eseigbe, 2009). Though no adverse health effect has been reported from intake of water containing even higher concentrations of chloride (Alexander 2008), chlorides are relatively harmless to organism except when converted to $\mathrm{Cl}_{2}, \mathrm{ClO}, \mathrm{ClO}_{3}$ which are toxic. High chloride content impacts taste and could cause corrosion.

The nutrients (nitrate and phosphate) which occur naturally in water are indices of organic pollution in water (Vollenweider, 1968). The levels of these nutrients vary seasonally in most African rivers and these variations are basically controlled by surface run-off and flooding (Imevbore, 1970; Egborge, 1970; Hall et al., 1977). Nitrogen enters the ground from several sources. Certain plants such as legumes fix atmospheric nitrogen and transfer it to the soil where it is used by plants. Some of the surplus nitrogen is removed in solution by downward percolating soil water. Other sources of soil nitrogen are decomposing plant debris, animal waste, household solid waste and nitrogen fertilizers. Additional nitrogen may enter groundwater from sewage discharge on land. Also, many industrial solid wastes contain high concentrations of nitrogen. Natural nitrate concentrations in groundwater range from 0.1 to $10 \mathrm{mg} / \mathrm{l}$ (Adeyemo et al., 2002). A nitrate content of more than 100mg/l impacts a bitter taste to water and may cause physiological problems. The safe nitrate limit for domestic water is set at $50 \mathrm{mg} / \mathrm{l}$. Drinking water which contains more than $50 \mathrm{mg} / \mathrm{l}$ nitrate can cause methamoglobinemia in infants. This is a disease caused by nitrate which is converted to nitrite in the intestines (Adeyemo et al., 2002).

Nitrate cannot be removed from water by boiling but must be treated by distillation. Nitrate was found in all the water samples collected but the values were very minute ranging between $0.02(\mathrm{mg} / \mathrm{l})$ and $0.13(\mathrm{mg} / \mathrm{l})$ showing a highly significant levels at $(\mathrm{P}<0.01)$ with control station being the highest. The range of values recorded is similar with works by. When asked, the landlord and occupants confirmed the sale of firewood and several pit latrines on the land. Furthermore, they continued, we have cultivated a small farmland, had some fruit trees whose dropping of leaves, application of fertilizer and decay of such over a long time. Going by the presence of the orchard, the sale of firewood, previous pit latrines and the application of fertilizers, it could be said that fertilizer application, decay of plants/leaves, human excreta might have had direct impact on the quality of ground water in this borehole. This is similar with earlier study carried out by Yerima et al. (2008) on the assessment of groundwater quality of Bama town, Nigeria. The low nitrate level in the borehole of the test stations is an indication of a low level of organic pollution in the water either due to the depth of borehole, soil formation or the topography as there were present of large quantities of industrial, domestic, agricultural waste at the dump-sites. Unpolluted natural waters usually contain only minute amounts of nitrate. An increase in nitrate in drinking water indicates contamination with wastewater, which can be attributed to poor sanitation, probably leaching of nitrates from the nearby pit latrines (Purandara et al., 2003).

In Nigeria, research work on nitrate levels in shallow wells was demonstrated to correlate with high human population density. Across the months, an insignificant difference $(\mathrm{P}>0.05)$ was obtained, although it recorded its highest mean concentrations in the month of July with a steady trend of decrease from July to December indicating that rainfall help in its percolation down the soil to ground water. The values recorded were 
all within the regulatory limits by FMEnv and WHO standards for maximum permissible levels but exceeded WHO standards for highest desirable.

The mean concentrations of phosphate ranged from $0.03(\mathrm{mg} / \mathrm{l})$ to $0.23(\mathrm{mg} / \mathrm{l})$ with a highly significant difference $(\mathrm{P}<0.01)$ across the stations recording its highest concentration in the control and the lowest in station 3. As earlier discussed for nitrate in which the highest value though minimal was recorded in the control, same goes for phosphate as their occurrence naturally in water are indices of organic pollution in water (Vollenweider, 1968). The values obtained were minimal and less than the regulatory limits set by FMEnv of $>5$. There was no significant difference $(\mathrm{P}>0.05)$ across the months but recorded its highest mean concentration in the month of July and the lowest in the month of December indicating also that rainfall help in its percolation down the soil to groundwater.

The results of the analysis indicated that the sulphate values ranged between $1.73(\mathrm{mg} / \mathrm{l})$ and $2.32(\mathrm{mg} / \mathrm{l})$ with an insignificant difference $(\mathrm{P}>0.05)$ across the study stations. Although the values were minimal, it was observed that the test stations were higher than the control station. The concentration values were below the regulatory limit by FMEnv. and WHO standards for highest desirable and max permissible levels. A study across the months revealed a significant difference $(\mathrm{P}<0.05)$ in the values obtained. There was a steady trend of decrease from the month of July to December. This showed seasonal monthly variations with the rainy season months having higher values while the dry season months recorded lower values.

Ammonium nitrogen concentration values ranged from $0.63(\mathrm{mg} / \mathrm{l})$ to $2.26(\mathrm{mg} / \mathrm{l})$ with no significant difference $(\mathrm{P}>0.05)$. Across the months, July recorded the highest value while December had the lowest mean value with a steady trend of decrease. This showed seasonal monthly variations with the rainy season months having higher values while the dry season months recorded lower values. The values obtained all exceeded WHO standards for highest desirable but were all within maximum permissible levels, while station 2 and 3 exceeded the regulatory limit set by FMEnv. of $<1.0$.

The spatial and temporal variation in total hydrocarbon for water is shown in Figure 3. The mean value of total hydrocarbon was highest $(0.02 \mathrm{mg} / \mathrm{l})$ in station 2 and lowest $(0.01 \mathrm{mg} / \mathrm{l})$ in station 4 across the sampled stations. Across the months, the highest mean value $(0.06 \mathrm{mg} / \mathrm{l})$ was recorded in July while the lowest mean value $(0.00 \mathrm{mg} / \mathrm{l})$ was in December. The one-way analysis of variance was used to examine the difference in means. There was no significant difference $(\mathrm{P}>0.05)$ across the stations while there was a highly significant difference ( $\mathrm{P}<0.01)$ found across the months. A posteriori DMR test revealed that July was highly significant from August, September, October, November and December which were not different from each other. 


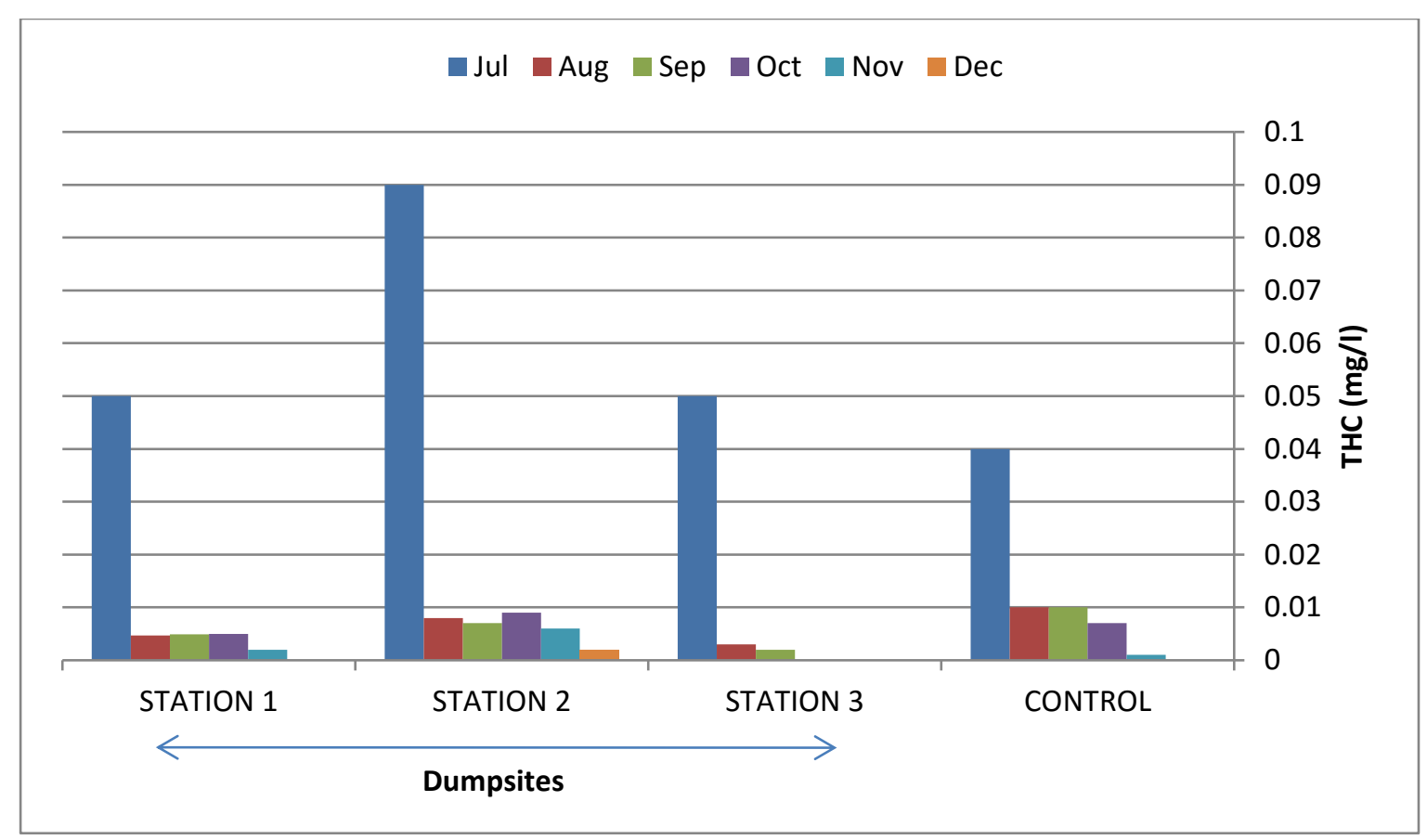

Figure 3: Spatial and temporal variations in total hydrocarbon at the study stations

Figure 4 shows a spatial and temporal variation in iron across the study stations and months. The highest $(0.45 \mathrm{mg} / \mathrm{l})$ and lowest $(0.20 \mathrm{mg} / \mathrm{l})$ mean values were recorded in stations 2 and 4 respectively. Statistically, there was a highly significant difference $(\mathrm{P}<0.01)$ among the studied stations. Station 2 was highly significant from stations 1 and 3 which were not different from each other, while station 4 was the lowest. Across the studied months, July and December recorded the highest $(0.52 \mathrm{mg} / \mathrm{l})$ and lowest $(0.16 \mathrm{mg} / \mathrm{l})$ mean values respectively. Statistically, a significant difference $(\mathrm{P}<0.05)$ was observed when tested with one-way analysis of variance. $A$ posteriori DMR test performed revealed that July was higher than August. The months of September, October, November and December which were not different from each other were the lowest. The spatial and temporal variation in zinc of borehole water is shown in Figure 5. The mean value of zinc was highest $(0.05 \mathrm{mg} / \mathrm{l})$ in station 3 and 4 and lowest $(0.03 \mathrm{mg} / \mathrm{l})$ in station 1 across the sampled stations. Across the months, the highest mean value $(0.05 \mathrm{mg} / \mathrm{l})$ was recorded in July while the lowest mean value $(0.04 \mathrm{mg} / \mathrm{l})$ was in August. The one-way analysis of variance was used to examine the difference in mean. There were no significant differences $(\mathrm{P}>0.05)$ found across the stations and months respectively.

The heavy metals concentrations were low in the groundwater samples and mean values of zinc and chromium were within WHO standards and regulatory limit set by FMEnv. Iron in the entire test stations were above the regulatory limit set by FMEnv of 0.3 while the control station was within. Iron concentrations in all the stations sampled all exceeded the WHO standards for highest desirable but were within the maximum permissible levels. The values for Manganese all exceeded the WHO standards for highest desirable levels but were within WHO maximum permissible levels and FMEnv. regulatory limits. Apart from copper which showed a significant difference $(\mathrm{P}<0.05)$, Iron, Zinc, Chromium and Manganese did not show any significant difference $(\mathrm{P}>0.05)$. Cadbium (mg/l), Nickel (mg/l), Lead (mg/l) and Vanadium (mg/l) were not detected among the heavy metals across the various stations sampled. 
Most groundwater supplies contain some iron because iron is common in many aquifers and is found in trace amounts in practically all sediments and rock formations. The iron content of groundwater is important because small amounts seriously affect water's usefulness for some domestic and industrial purposes. The World Health Organization recommends that the iron content of drinking water should not be greater than $0.3 \mathrm{mg} / \mathrm{l}$ because iron in water stains plumbing fixtures, stains cloths during laundering, incrusts well screens and clogs pipes (Deutsch, 2003). In Benin Metropolis, the Urban Water Board recommends 0.3mg/l of iron as the maximum expected limit. All the stations were above the WHO standards for highest desirable levels but were all within the maximum permissible levels. Stations 1,2 and 3 (test stations) were above the regulatory limit set by FMEnv. of 0.3. This could be due to its reaching natural waters mainly from leaching and flaking of rust from iron pipes as this borehole had iron pipes used in drilling from the ground and, it could also be related with the age of the borehole pipes. Across the months, a steady decrease from the month of July to December was observed with a significant difference $(\mathrm{P}<0.05)$. Iron values were higher than the other metals probably due to its ready source from industries and refuse dumps. Iron is highest in concentration in the test stations and lowest in the control borehole. Therefore, the possibility of the groundwater of the area being enriched with iron by the dump-site cannot be ruled out. This was similar to the findings by Ogbeibu et al., (2013) where the concentrations of iron in his test stations were higher than his control.

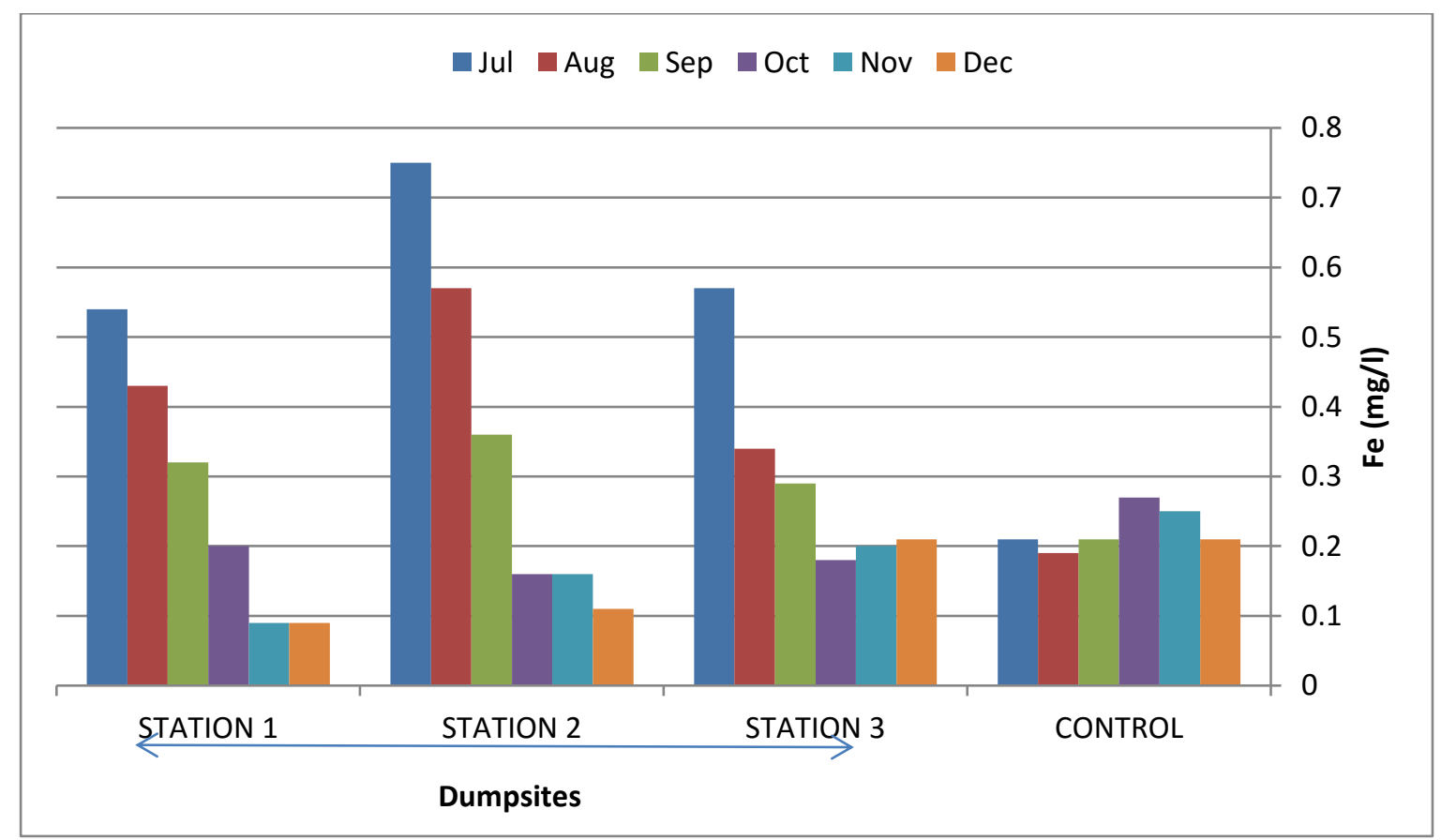

Figure 4: Spatial and temporal variations in iron at the study stations 


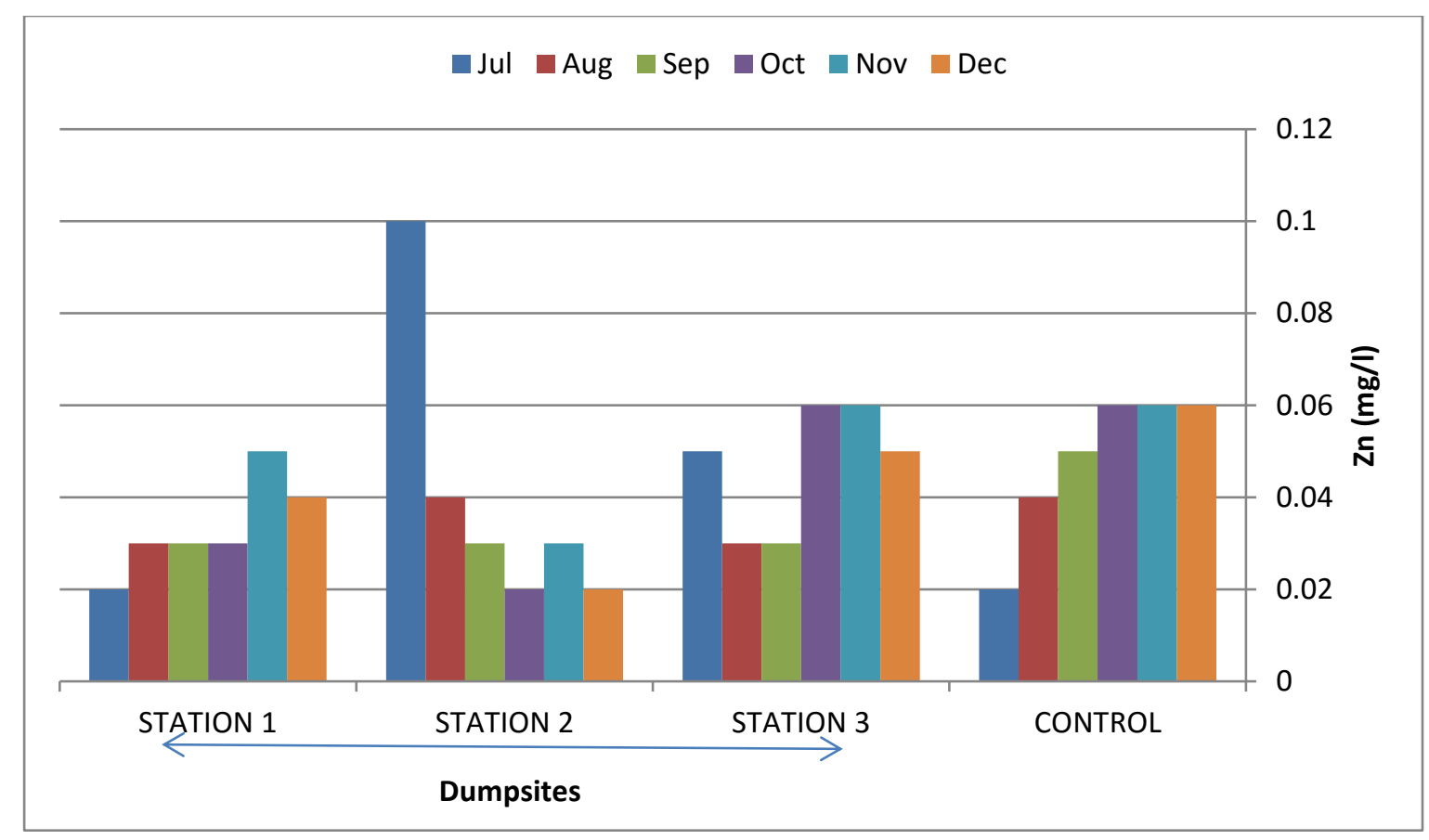

Figure 5: Spatial and temporal variations in zinc at the study stations

Manganese is widespread in rocks and minerals but less abundant than the other sesquioxide elements, iron and aluminum (Allen, 1989). Manganese resembles iron in its chemical behavior and its occurrence in groundwater is less abundant than iron. It is found to be lower than iron although in deep wells manganese may reach concentrations as high as $2-3 \mathrm{mg} / 1$. Solid waste when dissolved usually contains abundant manganese (Hughes, 2004). Manganese is objectionable in water in the same way as iron. It occurs as soluble manganese bicarbonate, which changes to insoluble manganese hydroxide when it reacts with atmospheric oxygen. Stains carried by manganese are more objectionable and harder to remove than iron. Therefore, drinking water regulations limit manganese concentrations to $0.05 \mathrm{mg} / \mathrm{l}$ to avoid manganese staining. From the result obtained, the manganese levels were higher than WHO's standards for highest desirable but within the maximum permissible levels and the regulatory limit set by FMEnv. of 0.5 . Across the month, there was a steady increase from the month of July to December with a highly significant difference $(\mathrm{P}<0.01)$. Both iron and manganese can be kept in solution by adding a small amount of Sodium hexameta-phosphate to the water (Wilham and Doris, 2005).

The range of zinc bearing minerals is not great but zinc is relatively more abundant than copper. Natural waters are normally low in zinc but effluents from industries such as rubber, plastics, batteries, pesticides, metallurgy, electroplating, metal finishing e.t.c., sewage and refuse dumps are sources of pollution. The values of zinc fluctuated between 0.03 and 0.05 which were within standards set by WHO and FMEnv. There was no significant difference $(\mathrm{P}>0.05)$ across the study stations and months. There was no defined pattern of seasonal monthly variation.

Copper occur essentially as sulphides and sometimes in combination with iron. Copper gets to the aquatic systems and groundwater through pesticides, corrosion of copper, brass and bronze fittings from metallurgy, paints and dyes manufacture of chemical and textiles. Copper salts are used also to control algal growth in reservoirs and control of slime in distributive systems. The concentration of copper across the stations fluctuated between $0.04(\mathrm{mg} / \mathrm{l})$ and $0.08(\mathrm{mg} / \mathrm{l})$ with a significant difference $(\mathrm{P}<0.05)$. Although it was within the set standard 
as earlier stated, only stations 3 and 4 were above the WHO standards for highest desirable levels. The control station was significantly different from station 3 . The reason for this cannot be ascertained. There was no significant difference $(\mathrm{P}>0.05)$ across the study months but it was highest in the month of July.

Chromium is sourced from granites and other basic rocks, some minerals and ores. It is widely distributed in soils but toxic to animals (Allen, 1989). It arises from discharge of waste from electroplating, manufacture of alloys and other industries such as paints and dyes, textiles, leather etc. Chromium concentrations in water were generally low (0.00) across the test and control stations and were all within the regulatory limits set by FMEnv. It was not significant $(\mathrm{P}>0.05)$ across the study stations and months.

The aerobic bacteria counts obtained from the results showed a significant difference $(\mathrm{P}<0.05)$ between the test stations and the control with station 1 significantly different from stations 2 and 3 which are not different from each other, while control station was the lowest. Fungi counts, total coliform counts, fecal coliforms, Salmonella-Shigalla and vibrio cholerae did not show any significant difference $(\mathrm{P}>0.05)$. It was also observed that apart from vibrio cholera which recorded 0.000 as the test value, and fecal coliforms where control station was second highest, the result clearly indicates that water samples collected were higher in all the test stations than the control stations. Across the months, there was a steady trend of seasonal monthly variation for aerobic bacterial counts, total coliform counts and fecal coliform with the rainy season months having higher values than the dry season months which recorded lower values. Fungi counts and Salmonella-Shigella did not show a defined seasonal variation.

The test values for the entire microbial assay tested except vibrio cholerea (0.000), showed values higher than the regulatory limit set by FMEnv. This is probably due to the present of dump-sites around the vicinity which receives both sewage and solid waste. The control station is void of such activities. From this standard set by FMEnv., it is clear that the water samples were not too safe for drinking and they have to be treated before drinking.

Tables 3 and 4 show the test of significance of microbial assay for borehole water sampled across the four stations and across the months using Kruskal-Wallis tests respectively (July 2011 to December 2011) in Benin Metropolis. Figure 6 shows a spatial and temporal variation in aerobic bacterial counts of borehole water across the study stations and months. The highest mean rank $\left(17.17 \times 10^{2} \mathrm{cfu} / \mathrm{ml}\right)$ and the lowest mean rank $\left(6.0 \times 10^{2} \mathrm{cfu} / \mathrm{ml}\right)$ were recorded in stations 1 and 4 respectively. Across the study months, July and December had the highest $\left(15.88 \times 10^{2} \mathrm{cfu} / \mathrm{ml}\right)$ and lowest $\left(8.50 \times 10^{2} \mathrm{cfu} / \mathrm{ml}\right)$ mean ranks respectively. Statistically, there was a significant difference $(\mathrm{P}<0.05)$ across the study stations and no significant difference $(\mathrm{P}>0.05)$ among the study months. A posteriori DMR test revealed that station 1 was significant from stations 2 and 3 which were not different from each other while station 4 was the lowest.

The spatial and temporal variation in fungi counts is shown in Figure 7. The highest mean rank (17.42 $\mathrm{x}$ $\left.10^{2} \mathrm{cfu} / \mathrm{ml}\right)$ and the lowest mean rank $\left(9.0 \times 10^{2} \mathrm{cfu} / \mathrm{ml}\right)$ were recorded in stations 3 and 4 respectively. The months of July and November had the highest $\left(15.12 \times 10^{2} \mathrm{cfu} / \mathrm{ml}\right)$ and lowest $\left(4.88 \times 10^{2} \mathrm{cfu} / \mathrm{ml}\right)$ mean ranks respectively. Statistically, there were no significant differences $(\mathrm{P}>0.05)$ across the sampled stations and months. 


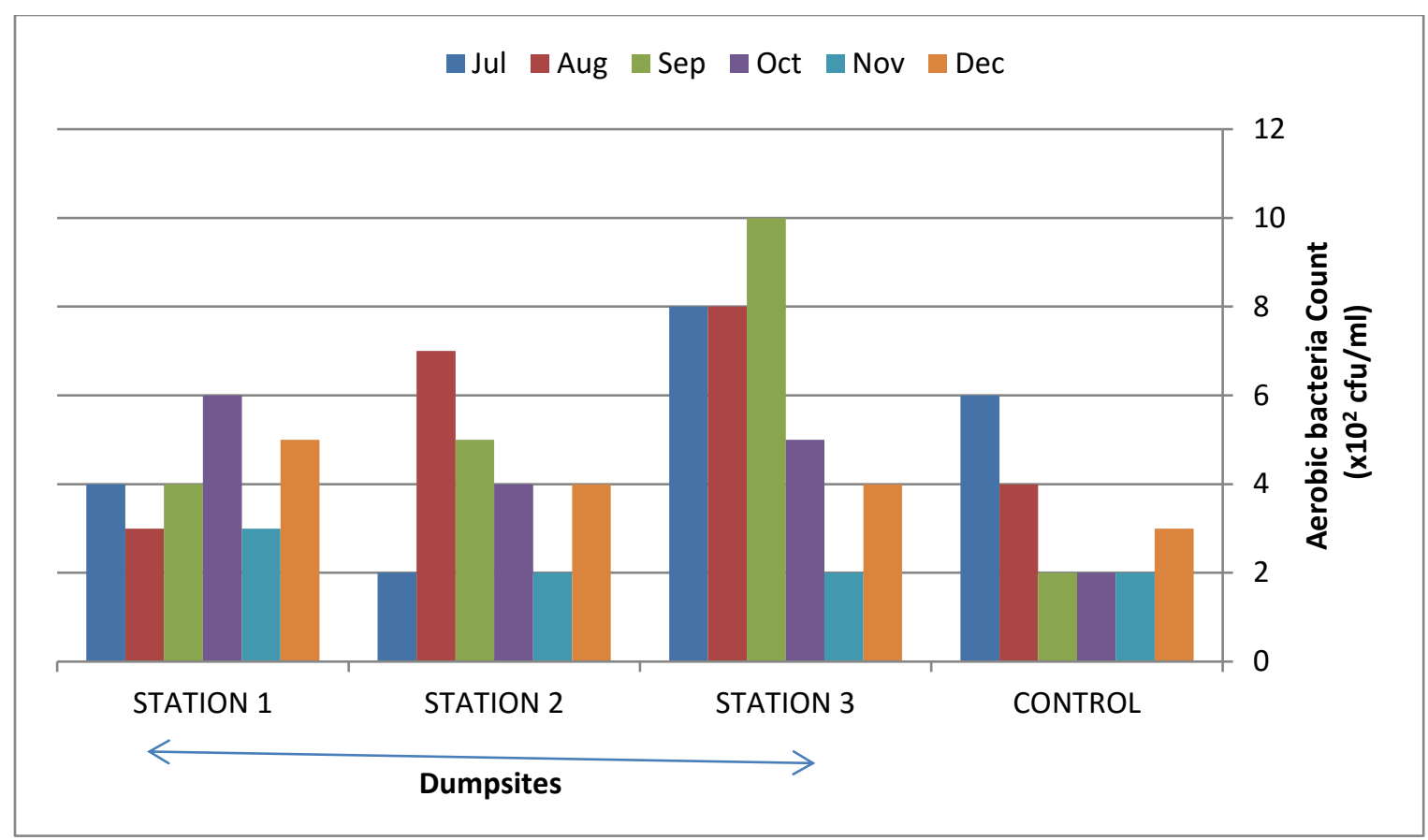

Figure 6: Spatial and temporal variations in aerobic bacteria counts at the study stations

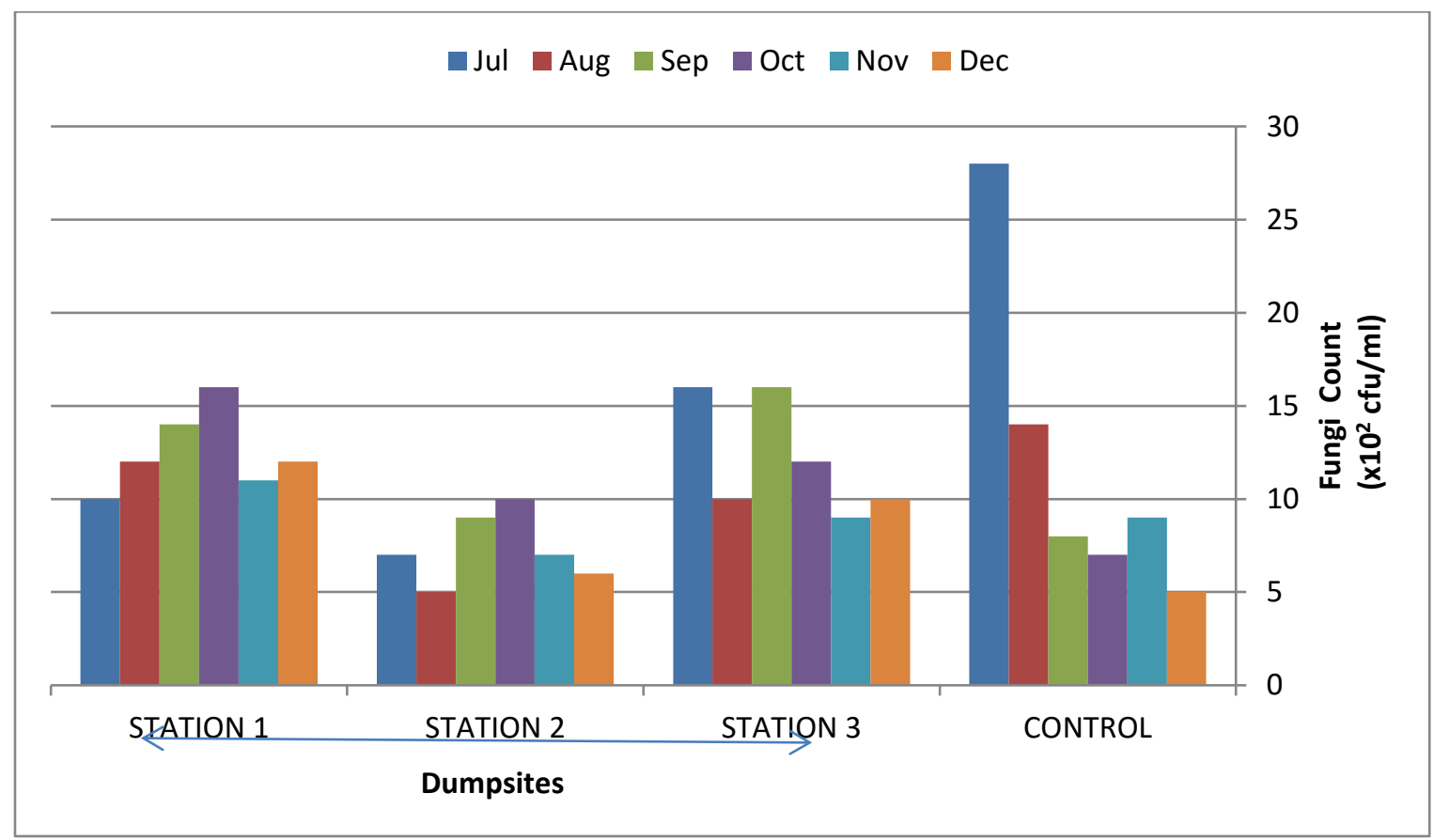

Figure 7: Spatial and temporal variations in fungi counts at the study stations

The highest and lowest mean ranks were recorded in stations 3 (16.0 MPN/100ml) and 4 (7.5 MPN/100ml) for total coliform, and stations $3(14.25 \mathrm{MPN} / 100 \mathrm{ml})$ and $2(12.33 \mathrm{MPN} / 100 \mathrm{ml})$ for fecal coliform respectively. There were no significant differences $(\mathrm{P}>0.05$ ) across the study stations for both coliforms. Across the study months, the highest and 
lowest mean ranks were recorded in July (19.12 MPN/100ml) and December (6.75 MPN/100ml) for total coliform; July (18.25 MPN/100ml) and October, November (6.50 MPN/100ml) for fecal coliform respectively. There was no significant difference $(\mathrm{P}>0.05)$ across the study months for total coliform while fecal coliforms was highly significant ( $\mathrm{P}<0.01)$ when tested with one-way analysis of variance. A posteriori DMR test revealed that July was highly significant from August and September which were not different from each other while October, November and December which were not also different from each other recorded the lowest.

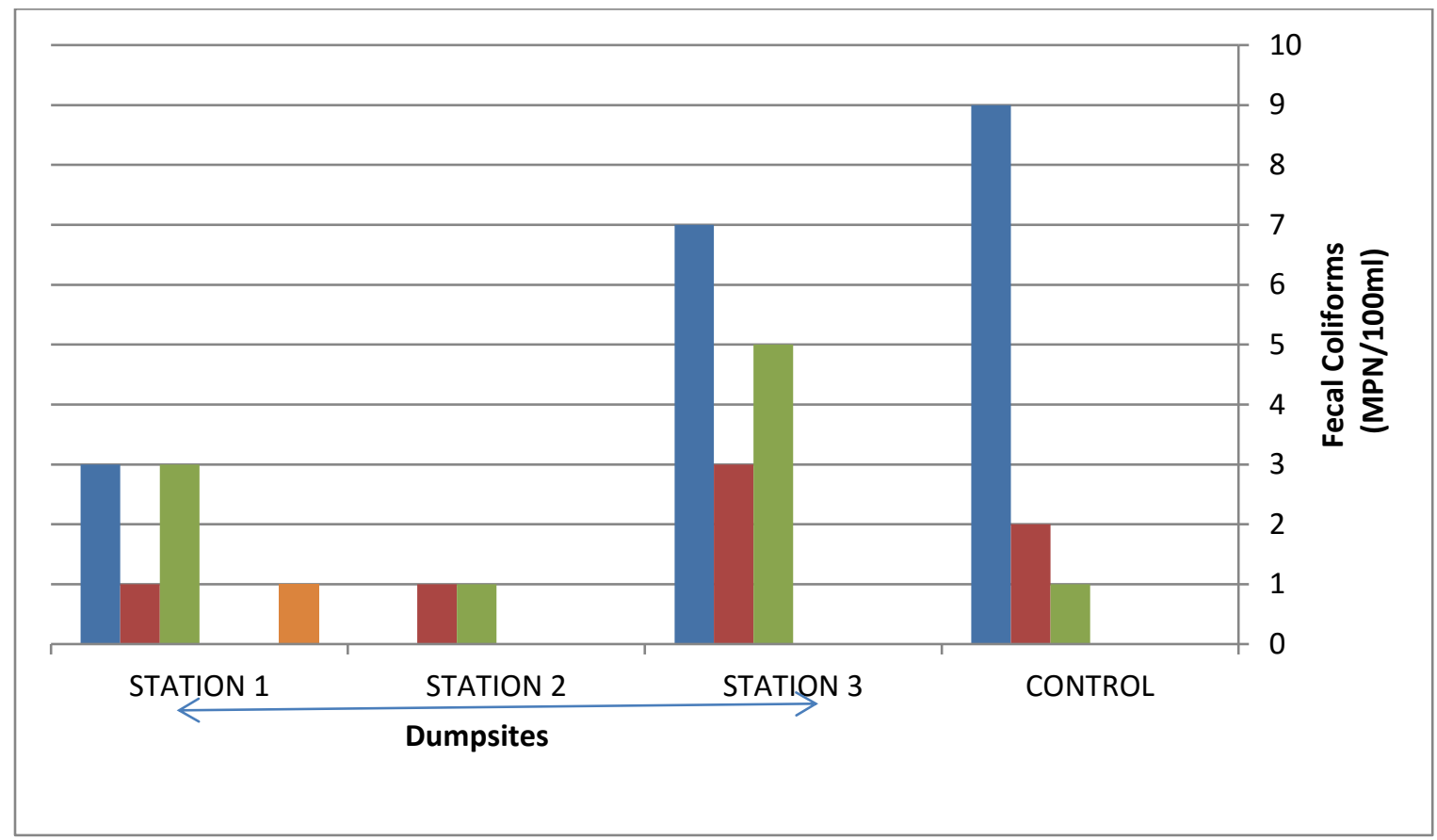

Figure 8: Spatial and temporal variations in fecal coliform at the study stations

The spatial and temporal variations of Salmonella-Shigella and vibrio cholerae of borehole water are shown in Figures 33 and 34 respectively. The highest and lowest mean ranks of Salmonella-Shigella and vibrio cholerae of borehole water were recorded in station $3\left(15.75 \times 10^{2} \mathrm{cfu} / \mathrm{ml}\right)$ and $4\left(8.00 \times 10^{2} \mathrm{cfu} / \mathrm{ml}\right)$ for salmonella-shigella while vibrio cholera recorded the same mean ranks across the four stations $\left(12.50 \times 10^{2} \mathrm{cfu} / \mathrm{ml}\right)$. Statistically, there were no significant differences $(\mathrm{P}>0.05)$ across the study stations for Salmonella-Shigella and vibrio cholerae when tested with one-way analysis of variance. 
Table 1: Comparison of mean values for physical and chemical parameters of borehole water sampled across the four stations in Benin metropolis using one -way ANOVA (July 2011 to December 2011).

\begin{tabular}{|c|c|c|c|c|c|c|c|c|c|c|c|c|c|c|c|c|}
\hline \multirow{2}{*}{ Parameters } & \multirow{2}{*}{$\mathbf{N}$} & \multicolumn{3}{|l|}{ STATION 1} & \multicolumn{3}{|l|}{ STATION 2} & \multicolumn{3}{|l|}{ STATION 3} & \multicolumn{3}{|l|}{ STATION 4} & \multirow{2}{*}{ P.Value } & \multirow{2}{*}{$\begin{array}{l}\text { Regulatory limits } \\
\text { FMEnv. }\end{array}$} & \multirow{2}{*}{$\begin{array}{l}\text { Highest desirable- } \\
\text { maximum permissible } \\
\text { wHO }\end{array}$} \\
\hline & & Mean \pm SE & Min & Max & Mean \pm SE & Min & Max & Mean \pm SE & Min & $\operatorname{Max}$ & Mean \pm SE & Min & Max & & & \\
\hline $\mathrm{pH}$ & 6 & $5.57^{2} \pm 0.08$ & 5.2 & 5.8 & $4.50^{\circ} \pm 0.10$ & 4.1 & 4.8 & $4.87^{b} \pm 0.16$ & 4.3 & 5.3 & $5.00^{b} \pm 0.12$ & 4.5 & 5.3 & $P<0.01$ & $6.5-8.5$ & $(6.5-9.2)$ \\
\hline Temp. $\left({ }^{\circ} \mathrm{C}\right)$ & 6 & $26.55 \pm 0.24$ & 26.7 & 27.5 & $26.50 \pm 0.28$ & 26.8 & 27.3 & $26.72 \pm 0.20$ & 26.8 & 27.1 & $26.48 \pm 0.15$ & 26.5 & 27.9 & $P>0.05$ & 30 & \\
\hline $\mathrm{EC}(\mu \mathrm{S} / \mathrm{cm})$ & 6 & $334.17^{b} \pm 28.12$ & 250 & 411 & $494.17^{\star 2} \pm 9.84$ & 456 & 530 & $394.33^{\mathrm{b}} \pm 36.16$ & 280 & 493 & $252.00^{c} \pm 19.04$ & 180 & 301 & P $<0.01$ & NA & \\
\hline Salinity $(g /)$ & 6 & $0.14^{b} \pm 0.02$ & 0.097 & 0.24 & $0.21^{2} \pm 0.01$ & 0.19 & 0.24 & $0.14^{b} \pm 0.01$ & 0.1 & 0.18 & $0.10^{\epsilon} \pm 0.01$ & 0.08 & 0.15 & $\mathbf{P}<0.01$ & 600 & \\
\hline TSS (mg/) & 6 & $1.22^{\mathrm{b}} \pm 0.255$ & 0 & 2 & $1.87^{a} \pm 0.080$ & 2 & 2 & $0.00^{c} \pm 0.00$ & 0 & 0 & $1.82^{\star} \pm 0.04$ & 2 & 2 & P $<0.01$ & 30 & \\
\hline TDS (m/l) & 6 & $175.83^{b} \pm 20.66$ & 120 & 256 & $239.83^{*} \pm 7.035$ & 213 & 260 & $189.50^{b} \pm 14.94$ & 140 & 224 & $128.00^{c} \pm 10.31$ & 90 & 149 & $P<0.01$ & 2000 & 600 \\
\hline DO (mg/) & 6 & $4.88 \pm 0.48$ & 3 & 6 & $4.75 \pm 0.39$ & 3 & 6 & $5.13 \pm 0.43$ & 4 & 6 & $4.50 \pm 0.36$ & 3 & 5 & P>0.05 & 5 & $>30$ \\
\hline $\mathrm{BOD}_{s}(\mathrm{mg} / \mathrm{l})$ & 6 & $3.03 \pm 0.53$ & 2 & 5 & $2.90 \pm 0.45$ & 1 & 4 & $3.53 \pm 0.61$ & 2 & 6 & $3.03 \pm 0.49$ & 1 & 4 & $P>0.05$ & & $>6.0$ \\
\hline $\operatorname{COD}(\mathrm{mg} / \mathrm{l})$ & 6 & $16.48^{b} \pm 1.40$ & 12.8 & 21 & $18.13^{*} \pm 1.51$ & 12 & 21.6 & $16.12^{b} \pm 0.91$ & 13.6 & 19.8 & $13.28^{8} \pm 1.71$ & 8 & 17.4 & P $<0.01$ & 40 & \\
\hline $\left.\mathrm{HCO}_{3} \mathrm{mg} / \mathrm{l}\right)$ & 6 & $17.28^{b} \pm 1.19$ & 12.2 & 21 & $15.20^{\circ} \pm 1.01$ & 12.2 & 19.3 & $11.17^{\circ} \pm 1.54$ & 6.1 & 16.2 & $29.02^{2} \pm 2.83$ & 18.3 & 35 & $P<0.01$ & 30 & \\
\hline $\mathrm{Ca}(\mathrm{mg} / \mathrm{l})$ & 6 & $0.90^{\epsilon} \pm 0.19$ & 0.52 & 1.75 & $17.39^{\circ} \pm 1.72$ & 11.6 & 23.8 & $1.21^{\mp} \pm 0.29$ & 0.65 & 2.56 & $10.64^{b} \pm 2.34$ & 3.01 & 17.2 & $P<0.01$ & 200 & $(75-200)$ \\
\hline $\mathrm{Na}(\mathrm{mg} / \mathrm{l})$ & 6 & $0.45^{b} \pm 0.01$ & 0.41 & 0.48 & $20.22^{2} \pm 3.90$ & 2.06 & 28.2 & $0.36^{6} \pm 0.01$ & 0.32 & 0.4 & $14.82^{2} \pm 0.47$ & 13.1 & 16.1 & $P<0.01$ & 200 & \\
\hline $\mathrm{K}(\mathrm{mg} / \mathrm{l})$ & 6 & $0.36^{\mathrm{c}} \pm 0.03$ & 0.29 & 0.45 & $20.42^{2} \pm 2.73$ & 10.5 & 26.6 & $0.47^{c} \pm 0.04$ & 0.35 & 0.65 & $13.72^{\prime \prime} \pm 1.30$ & 9.33 & 16.9 & $P<0.01$ & $\mathrm{NA}$ & \\
\hline $\mathrm{Mg}(\mathrm{mg} / \mathrm{l})$ & 6 & $0.11^{c} \pm 0.01$ & 0.09 & 0.16 & $2.09^{2} \pm 0.13$ & 1.78 & 2.64 & $0.13^{c} \pm 0.02$ & 0.09 & 0.21 & $1.36^{b} \pm 0.06$ & 1.21 & 1.59 & $P<0.01$ & 150 & $(30-150)$ \\
\hline $\mathrm{Cl}(\mathrm{mg} / \mathrm{l})$ & 6 & $21.46^{\circ} \pm 4.91$ & 10.75 & 40.3 & $45.07^{2} \pm 8.97$ & 25.4 & 80.3 & $22.04^{b} \pm 5.11$ & 11.4 & 40.6 & $34.68^{\circ} \pm 2.66$ & 23.7 & 41.2 & $P<0.05$ & 600 & $(200-600)$ \\
\hline $\mathrm{SO}_{4}(\mathrm{mg} / \mathrm{l})$ & 6 & $2.16 \pm 0.16$ & 1.48 & 2.59 & $2.32 \pm 0.34$ & 1.21 & 3.16 & $1.83 \pm 0.16$ & 1.28 & 2.23 & $1.73 \pm 0.24$ & 1.04 & 2.46 & P>0.05 & 500 & $(200-400)$ \\
\hline $\mathrm{PO}_{4}(\mathrm{mg} / \mathrm{l})$ & 6 & $0.04^{c} \pm 0.01$ & 0.01 & 0.09 & $0.16^{6} \pm 0.05$ & 0.01 & 0.28 & $0.03^{c} \pm 0.01$ & 0.01 & 0.06 & $0.23^{*} \pm 0.06$ & 0.01 & 0.46 & $\mathbf{P}<0.01$ & $>5$ & \\
\hline NH.N mg/l) & 6 & $0.63 \pm 0.35$ & 0.01 & 1.91 & $2.26 \pm 1.09$ & 0.02 & 6.42 & $1.52 \pm 0.93$ & 0.03 & 5.41 & $0.77 \pm 0.32$ & 0.01 & 1.91 & $P>0.05$ & $<1.0$ & (Absent-17) \\
\hline $\mathrm{NO}_{2}(\mathrm{mg} / \mathrm{l})$ & 6 & $0.01 \pm 0.00$ & 0 & 0.03 & $0.03 \div 0.02$ & 0 & 0.05 & $0.04 \pm 0.01$ & 0.02 & 0.06 & $0.04 \pm 0.01$ & 0.02 & 0.06 & $P>0.05$ & 1 & (Absent-0.5) \\
\hline $\mathrm{NO}_{3}(\mathrm{mg} / \mathrm{l})$ & 6 & $0.02^{c} \pm 0.01$ & 0 & 0.07 & $0.10^{6} \pm 0.03$ & 0.03 & 0.25 & $0.07^{\complement} \pm 0.01$ & 0.03 & 0.1 & $0.13^{n} \pm 0.01$ & 0.09 & 0.15 & $P<0.01$ & 10 & (Absent-0.5) \\
\hline $\mathrm{Fe}(\mathrm{mg} / \mathrm{l})$ & 6 & $0.38^{b} \pm 0.08$ & 0.09 & 0.54 & $0.45^{ \pm} \pm 0.11$ & 0.11 & 0.75 & $0.32^{b} \pm 0.01$ & 0.19 & 0.51 & $0.20^{\circ} \pm 0.06$ & 0.18 & 0.47 & $P<0.01$ & 0.3 & $(0.1-1.0)$ \\
\hline Mn (mg/) & 6 & $0.06 \pm 0.02$ & 0 & 0.11 & $0.11 \pm 0.04$ & 0 & 0.24 & $0.19 \pm 0.06$ & 0 & 0.34 & $0.22 \pm 0.07$ & 0 & 0.43 & $P>0.05$ & 0.5 & $(0.05-0.5)$ \\
\hline $\mathrm{Zn}(\mathrm{mg} /)$ & 6 & $0.03 \pm 0.00$ & 0.02 & 0.05 & $0.04 \pm 0.01$ & 0.02 & 0.1 & $0.05 \pm 0.01$ & 0.03 & 0.06 & $0.05 \pm 0.01$ & 0.02 & 0.06 & $P>0.05$ & 15 & $(5-15)$ \\
\hline $\mathrm{Cu}(\mathrm{mg} / \mathrm{l})$ & 6 & $0.04^{b} \pm 0.01$ & 0.02 & 0.1 & $0.04^{b} \pm 0.02$ & 0.01 & 0.11 & $0.06 \pm^{b} 0.01$ & 0.05 & 0.09 & $0.08^{*} \pm 0.00$ & 0.07 & 0.09 & $P<0.05$ & 1.5 & $0.05-1.5$ \\
\hline $\mathrm{Cr}(\mathrm{mg} / \mathrm{l})$ & 6 & $0.00 \pm 0.00$ & 0 & 0.001 & $0.00 \pm 0.00$ & 0 & 0.01 & $0.00 \pm 0.00$ & 0 & 0.01 & $0.00 \pm 0.00$ & 0 & 0 & $P>0.05$ & 0.05 & \\
\hline THC $(\mathrm{mg} / \mathrm{l})$ & 6 & $0.01 \pm 0.01$ & 0 & 0.05 & $0.02 \pm 0.01$ & 0 & 0.09 & $0.01 \pm 0.01$ & 0 & 0.05 & $0.01 \pm 0.01$ & 0 & 0.04 & $P>0.05$ & 0.5 & \\
\hline
\end{tabular}

Note: $\mathrm{Cd}(\mathrm{mg} / \mathrm{l}), \mathrm{Ni}(\mathrm{mg} / \mathrm{l}), \mathrm{Pb}(\mathrm{mg} / \mathrm{l}), \mathrm{V}(\mathrm{mg} / \mathrm{l})$ are not detected among the Heavy metals. $\boldsymbol{P}>0.05-$ Not Significant, $\boldsymbol{P}<\mathbf{0 . 0 5 -}$ Significant, $\boldsymbol{P}<0.01-$ Highly Significant. Mea

Table 2: Comparison of mean values for physical and chemical parameters of borehole water sampled from July 2011 to December 2011 in Benin Metropolis using one-way ANOVA

\begin{tabular}{|c|c|c|c|c|c|c|c|c|c|c|c|c|c|c|c|c|}
\hline \multirow{2}{*}{ MONTHS / PARAMETERS } & \multirow{2}{*}{$\mathrm{N}$} & \multicolumn{3}{|c|}{ JULY } & \multicolumn{3}{|c|}{ AUGUST } & \multicolumn{3}{|c|}{ SEPTEMBER } & \multicolumn{3}{|c|}{ OCTOBER } & \multicolumn{3}{|c|}{ NOVEMBER } \\
\hline & & Mean \pm SE & Min & Max & Mean \pm SE & Min & Max & Mean \pm SE & Min & $\operatorname{Max}$ & Mean \pm SE & Min & $\operatorname{Max}$ & Mean \pm SE & Min & Max \\
\hline $\mathrm{pH}$ & 4 & $4.80 \pm 0.35$ & 4.1 & 5.5 & $4.83 \pm 0.17$ & 4.5 & 5.2 & $4.95 \pm 0.18$ & 4.8 & 5.6 & $5.03 \pm 0.34$ & 4.3 & 5.6 & $5.05 \pm 0.21$ & 4.6 & 5.7 \\
\hline Temperature $\left({ }^{\circ} \mathrm{C}\right.$ ) & 4 & $26.18^{4} \pm 0.13$ & 26.3 & 26.5 & $26.58^{d} \pm 0.15$ & 26.4 & 26.6 & $26.83^{\mathrm{d}} \pm 0.06$ & 26.5 & 26.7 & $26.95^{\star} \pm 0.16$ & 27 & 27.2 & $27.02^{b} \pm 0.15$ & 27.3 & 27.5 \\
\hline $\mathrm{EC}(\mu \mathrm{S} / \mathrm{cm})$ & 4 & $310.0^{c} \pm 76.27$ & 180 & 430 & $329.75^{\mathrm{c}} \pm 60.06$ & 230 & 487 & $344.75^{\mathrm{C}} \pm 53.53$ & 233 & 497 & $407.00^{h} \pm 51.42$ & 270 & 490 & $419.50^{b} \pm 48.24$ & 298 & 501 \\
\hline Salinity $(\mathrm{g} / \mathrm{l})$ & 4 & $0.12 \pm 0.03$ & 0.081 & 0.19 & $0.13 \pm 0.02$ & 0.097 & 0.24 & $0.13 \pm 0.03$ & 0.1 & 0.23 & $0.15 \pm 0.03$ & 0.107 & 0.233 & $0.17 \pm 0.01$ & 0.14 & 0.2 \\
\hline TSS (mg/) & 4 & $1.30 \pm 0.46$ & 0 & 2.1 & $1.25 \pm 0.44$ & 0 & 2 & $1.30 \pm 0.45$ & 0 & 2 & $0.95 \pm 0.55$ & 0 & 2 & $1.23 \pm 0.41$ & 0 & 1.8 \\
\hline TDS (mg/) & 4 & $152.50 \pm 37.28$ & 90 & 260 & $161.00 \pm 32.91$ & 102 & 254 & $179.50 \pm 22.77$ & 142 & 244 & $199.75 \pm 21.99$ & 140 & 240 & $193.50 \pm 16.72$ & 145 & 218 \\
\hline $\mathrm{DO}(\mathrm{mg} / \mathrm{l})$ & 4 & $3.45^{c} \pm 0.16$ & 3.1 & 3.8 & $3.80^{\circ} \pm 0.14$ & 3.4 & 4 & $4.73^{b} \pm 0.06$ & 4.6 & 4.9 & $5.53^{2} \pm 0.19$ & 5.1 & 5.9 & $5.55^{a} \pm 0.22$ & 5 & 6 \\
\hline $\mathrm{BOD}_{s}(\mathrm{mg} / \mathrm{l})$ & 4 & $1.45^{4} \pm 0.06$ & 1.3 & 1.6 & $2.13^{d} \pm 0.16$ & 1.9 & 2.6 & $2.78^{\mathrm{e}} \pm 0.10$ & 2.6 & 3 & $3.60^{\circ} \pm 0.07$ & 3.4 & 3.7 & $4.23^{b} \pm 0.54$ & 3.5 & 5.8 \\
\hline $\mathrm{COD}(\mathrm{mg} / \mathrm{l})$ & 4 & $11.60^{4} \pm 1.24$ & 8 & 13.6 & $13.35^{4} \pm 1.34$ & 9.7 & 16 & $14.58^{d} \pm 1.40$ & 11 & 17.8 & $17.95^{c} \pm 0.79$ & 16.6 & 20 & $18.60^{b} \pm 1.05$ & 17 & 21.4 \\
\hline $\mathrm{HCO}_{3}(\mathrm{mg} / \mathrm{l})$ & 4 & $12.20 \pm 2.49$ & 6.1 & 18.3 & $15.63 \pm 3.12$ & 8.3 & 23.4 & $17.53 \pm 3.98$ & 10 & 28.6 & $19.70 \pm 4.93$ & 12.2 & 34 & $21.08 \pm 4.66$ & 14.2 & 34.8 \\
\hline $\mathrm{Ca}(\mathrm{mg} / \mathrm{l})$ & 4 & $3.95 \pm 2.62$ & 0.52 & 11.61 & $5.41 \pm 3.28$ & 0.56 & 14.55 & $6.56 \pm 3.73$ & 0.67 & 16.4 & $8.74 \pm 4.59$ & 0.8 & 18.73 & $9.21 \pm 4.69$ & 1.07 & 19.23 \\
\hline $\mathrm{Na}(\mathrm{mg} / \mathrm{l})$ & 4 & $8.38 \pm 4.81$ & 0.32 & 19.67 & $8.65 \pm 4.89$ & 0.36 & 14.75 & $9.36 \pm 3.42$ & 0.36 & 19.56 & $10.45 \pm 6.16$ & 0.35 & 25.48 & $10.65 \pm 6.28$ & 0.38 & 26.12 \\
\hline $\mathrm{K}(\mathrm{mg} / \mathrm{l})$ & 4 & $5.18 \pm 2.76$ & 0.39 & 10.53 & $6.54 \pm 3.61$ & 0.42 & 14.6 & $8.42 \pm 4.80$ & 0.37 & 19.6 & $10.44 \pm 6.18$ & 0.29 & 25.46 & $10.77 \pm 6.28$ & 0.3 & 25.76 \\
\hline $\mathrm{Mg}(\mathrm{mg} / \mathrm{l})$ & 4 & $1.10 \pm 0.62$ & 0.09 & 2.64 & $0.92 \pm 0.50$ & 0.09 & 2.08 & $0.92 \pm 0.50$ & 0.1 & 2.11 & $0.83 \pm 0.43$ & 0.11 & 1.82 & $0.90 \pm 0.47$ & 0.1 & 2.08 \\
\hline $\mathrm{Cl}(\mathrm{mg} / \mathrm{l})$ & 4 & $50.38^{\star} \pm 9.98$ & 40.3 & 80.3 & $41.98^{b} \pm 7.15$ & 30.2 & 62.3 & $31.08^{\epsilon} \pm 5.48$ & 20.6 & 43.2 & $21.83^{e} \pm 6.22$ & 10.8 & 33.4 & $20.26^{\circ} \pm 5.11$ & 11.2 & 32.1 \\
\hline $\mathrm{SO}_{4}(\mathrm{mg} /)$ & 4 & $2.50^{\mathrm{A}} \pm 0.28$ & 1.79 & 3.16 & $2.31^{b} \pm 0.39$ & 1.28 & 3.15 & $2.26^{6} \pm 0.18$ & 1.93 & 2.79 & $2.04^{4} \pm 0.11$ & 1.74 & 2.23 & $1.65^{5} \pm 0.22$ & 1.04 & 2.03 \\
\hline $\mathrm{PO}_{4}(\mathrm{mg} / \mathrm{l})$ & 4 & $0.16 \pm 0.05$ & 0.06 & 0.28 & $0.15 \pm 0.04$ & 0.04 & 0.32 & $0.14 \pm 0.07$ & 0.03 & 0.21 & $0.10 \pm 0.11$ & 0.02 & 0.16 & $0.05 \pm 0.04$ & 0.01 & 0.1 \\
\hline $\mathrm{NH}_{4} \mathrm{~N}(\mathrm{mg} / \mathrm{l})$ & 4 & $3.91^{2} \pm 1.17$ & 1.91 & 6.42 & $2.60^{b} \pm 0.73$ & 1.29 & 4.37 & $1.13^{c} \pm 0.51$ & 0.18 & 2.43 & $0.12^{2} \pm 0.03$ & 0.07 & 0.18 & $0.08^{c} \pm 0.03$ & 0.02 & 0.14 \\
\hline $\mathrm{NO}_{2}(\mathrm{mg} / \mathrm{l})$ & 4 & $0.07^{\natural} \pm 0.02$ & 0.03 & 0.12 & $0.03^{b} \pm 0.01$ & 0.01 & 0.06 & $0.02^{b} \pm 0.01$ & 0 & 0.04 & $0.02^{\mathrm{b}} \pm 0.01$ & 0 & 0.04 & $0.01^{b} \pm 0.01$ & 0 & 0.03 \\
\hline $\mathrm{NO}_{3}(\mathrm{mg} /)$ & 4 & $0.14 \pm 0.04$ & 0.07 & 0.25 & $0.11 \pm 0.03$ & 0.04 & 0.18 & $0.09 \pm 0.03$ & 0.02 & 0.15 & $0.08 \pm 0.03$ & 0 & 0.15 & $0.05 \pm 0.02$ & 0 & 0.11 \\
\hline $\mathrm{Fe}(\mathrm{mg} / \mathrm{l})$ & 4 & $0.52^{2} \pm 0.11$ & 0.21 & 0.75 & $0.38^{b} \pm 0.08$ & 0.19 & 0.57 & $0.30^{\circ} \pm 0.03$ & 0.21 & 0.36 & $0.20^{\circ} \pm 0.02$ & 0.16 & 0.27 & $0.18^{c} \pm 0.03$ & 0.09 & 0.25 \\
\hline $\mathrm{Mn}(\mathrm{mg} /)$ & 4 & $0.00^{\circ} \pm 0.00$ & 0 & 0 & $0.04^{e} \pm 0.02$ & 0 & 0 & $0.09^{4} \pm 0.02$ & 0 & 0 & $0.23^{\mathrm{b}} \pm 0.08$ & 0 & 0 & $0.24^{b} \pm 0.05$ & 0 & 0 \\
\hline $\mathrm{Zn}(\mathrm{mg} / \mathrm{l})$ & 4 & $0.05 \pm 0.02$ & 0.02 & 0.1 & $0.04 \pm 0.00$ & 0.03 & 0.04 & $0.04 \pm 0.01$ & 0.03 & 0.05 & $0.04 \pm 0.01$ & 0.02 & 0.06 & $0.05 \pm 0.01$ & 0.03 & 0.06 \\
\hline $\mathrm{Cu}(\mathrm{mg} / \mathrm{l})$ & 4 & $0.09 \pm 0.01$ & 0.1 & 0.1 & $0.05 \pm 0.02$ & 0 & 0.1 & $0.04 \pm 0.02$ & 0 & 0.1 & $0.04 \pm 0.02$ & 0 & 0.1 & $0.05 \pm 0.01$ & 0 & 0.1 \\
\hline $\mathrm{Cr}(\mathrm{mg} / \mathrm{l})$ & 4 & $0.00 \pm 0.00$ & 0.001 & 0.005 & $0.00 \pm 0.00$ & 0 & 0.01 & $0.00 \pm 0.00$ & 0 & 0.002 & $0.00 \pm 0.00$ & 0 & 0 & $0.00 \pm 0.00$ & 0 & 0 \\
\hline $\mathrm{THC}$ (mg/) & 4 & $0.06^{\mathrm{a}} \pm 0.01$ & 0.04 & 0.09 & $0.01^{\mathrm{b}} \pm 0.00$ & 0 & 0.01 & $0.01^{11} \pm 0.00$ & 0 & 0.01 & $0.01^{\mathrm{b}} \pm 0.00$ & 0 & 0.01 & $0.00^{b} \pm 0.00$ & 0 & 0.01 \\
\hline
\end{tabular}

Note: P>0.05- Not Significant, P<0.05- Significant, P<0.01- Highly Significant. Means with same superscript (in row) are not significant from each other. 
Table 3: Comparison of mean rank for microbial assay of borehole water sampled across the four stations in Benin Metropolis using Kruskal-Wallis tests

\begin{tabular}{|c|c|c|c|c|c|c|c|c|c|}
\hline \multirow[t]{2}{*}{ Parameter } & \multirow[t]{2}{*}{$\mathrm{N}$} & \multicolumn{4}{|c|}{ Dumpsites (mean rank) } & \multirow[t]{2}{*}{ df } & \multirow[t]{2}{*}{ Test value } & \multirow[t]{2}{*}{ P-value } & \multirow{2}{*}{$\begin{array}{c}\text { Permissible Limi } \\
\text { Standard } \\
\text { FMEnv(mg/l) }\end{array}$} \\
\hline & & IKHUENIRO & COSTAIN & UGBIYOKO & OMAGHE & & & & \\
\hline Aerobic bacteria counts $\left(\times 10^{2} \mathrm{cfu} / \mathrm{ml}\right)$ & 6 & $17.17^{\mathrm{a}}$ & $11.00^{\mathrm{b}}$ & $15.83^{\mathrm{b}}$ & $6.00^{c}$ & 3 & 9.401 & $P<0.05$ & 0 \\
\hline Fungi counts $\left(\times 10^{2} \mathrm{cfu} / \mathrm{ml}\right.$ & 6 & 14.08 & 9.5 & 17.42 & 9 & 3 & 5.962 & $P>0.05$ & 0 \\
\hline Total coliforms MPN/100ml & 6 & 13.75 & 12.75 & 16 & 7.5 & 3 & 4.811 & $P>0.05$ & 0 \\
\hline Fecal coliforms (E.Coli) MPN/100ml & 6 & 12.67 & 12.33 & 14.25 & 12.75 & 3 & 2.01 & $P>0.05$ & 0 \\
\hline Salmonella-Shigella $\left(\times 10^{2} \mathrm{cfu} / \mathrm{ml}\right)$ & 6 & 15.33 & 10.92 & 15.75 & 8 & 3 & 5.643 & $\mathrm{P}>0.05$ & 0 \\
\hline Vibrio cholerae $\left(\times 10^{2} \mathrm{cfu} / \mathrm{ml}\right)$ & 6 & 12.5 & 12.5 & 12.5 & 12.5 & 3 & 0 & $P>0.05$ & 0 \\
\hline
\end{tabular}

Note: $P<0.05$ - Significant, $P>0.05$-Not Significant. Means with same superscript (in row) are not significant from each other.

TABLE 4: Comparison of mean rank for microbial assay of borehole water sampled from July 2011 to December 2011 in Benin Metropolis using Kruskal-Wallis tests

\begin{tabular}{|c|c|c|c|c|c|c|c|c|c|c|}
\hline \multirow[t]{2}{*}{ Parameter } & \multirow[t]{2}{*}{$\mathrm{N}$} & \multicolumn{5}{|c|}{ Monthly sampling (mean rank) } & \multirow[b]{2}{*}{ DECEMBER } & \multirow[t]{2}{*}{ df } & \multirow[t]{2}{*}{ Test value } & \multirow[t]{2}{*}{ P-value } \\
\hline & & JULY & AUGUST & SEPTEMBER & OCTOBER & NOVEMBER & & & & \\
\hline Aerobic bacteria counst $\left(\mathrm{x} 10^{2} \mathrm{cfu} / \mathrm{ml}\right)$ & 4 & 15.88 & 14.62 & 14.38 & 14.12 & 9.50 & 8.50 & 5 & 3.447 & $P>0.05$ \\
\hline Fungi counts $\left(\times 10^{2} \mathrm{cfu} / \mathrm{ml}\right.$ & 4 & 15.12 & 14.62 & 14.88 & 14.00 & 4.88 & 12.50 & 5 & 6.152 & $P>0.05$ \\
\hline Total coliforms MPN/100ml & 4 & 19.12 & 16.62 & 16.50 & 11.25 & 8.75 & 6.75 & 5 & 8.960 & $\mathrm{P}>0.05$ \\
\hline Salmonella-Shigella $\left(\times 10^{2} \mathrm{cfu} / \mathrm{ml}\right.$ & 4 & 11.25 & 7.50 & 12.75 & 15.38 & 13.38 & 14.75 & 5 & 4.065 & $P>0.05$ \\
\hline Vibrio cholerae $\left(\times 10^{2} \mathrm{cfu} / \mathrm{ml}\right)$ & 4 & 12.50 & 12.50 & 12.50 & 12.50 & 12.50 & 12.50 & 5 & 0.000 & $P>0.05$ \\
\hline
\end{tabular}

Note: $P<0.01-$ Highly Significant, $P>0.05$ - Not Significant. Means with same superscript (in row) are not significant from each other.

Table 5: The test of interaction of physicochemical, heavy metals with microbial assay for borehole water using Pearson's correlation.

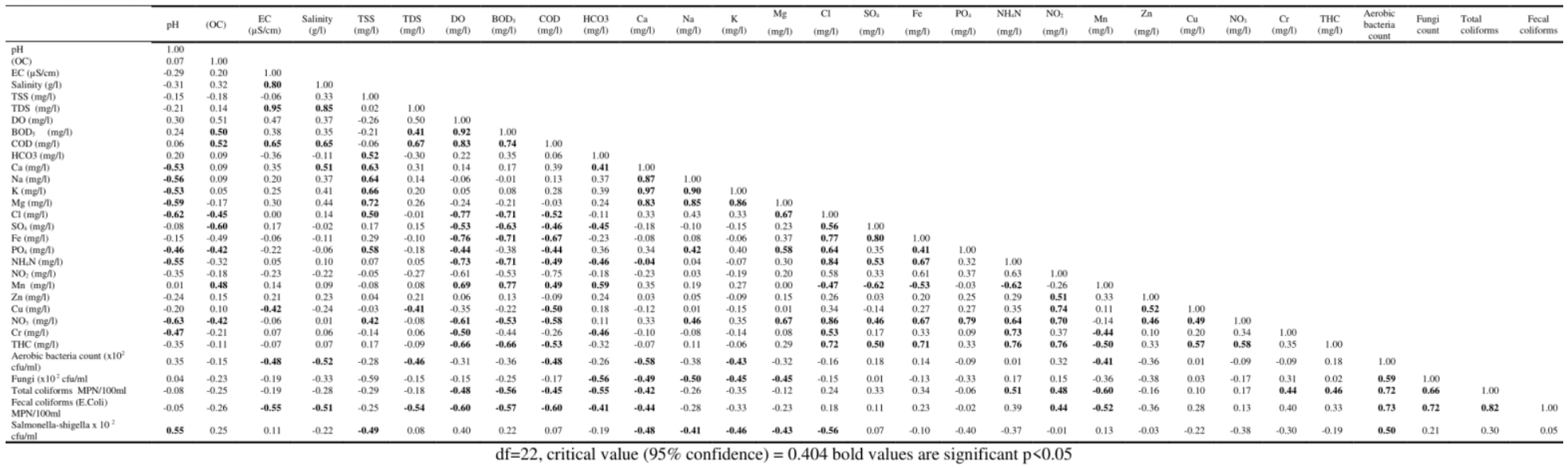


The correlation between the borehole water parameters investigated showed that among all the parameters tested only calcium was significantly negatively correlated with bacteria counts, fungi counts, total coliforms, fecal coliforms and Salmonella- Shigella (Table 5). This indicated that calcium is important in determining the presence and growth of the microorganisms in borehole water. Abundance of calcium would affect the presence of microorganisms in water. The same was the result for electrical conductivity, salinity, total suspended solids, total dissolve solids, dissolved oxygen, biochemical oxygen demand, chemical oxygen demand, hydrogen trioxocarbonate, sodium, potassium, magnesium, and manganese.

However, there was a positive correlation between fungi count, total coliforms, fecal coliforms and Salmonella- Shigella with bacteria counts. The same was the result for hydrogen ion concentration, ammonium nitrogen and nitrite. Hence, same factor that increases or decreases fungi counts, total coliforms, fecal coliforms and Salmonella- Shigella also affect bacteria counts.

\section{CONCLUSION}

This study has evaluated groundwater around various dump-sites which have been shown to be impacted by contamination. There was evidence of chemical, physical and microbiological pollution based on the findings of this study. The comparison of concentrations for the various parameters among the borehole water sampled shows clearly that the presence of dump-sites is a significant source of pollutants. Most of the parameters examined showed that sampling stations around dump-sites had higher values than the control stations. Although, few of the parameters tested were above the recommended standards set by FMEnv. and WHO. The nature of waste disposed into the dumpsites, the age of dump-sites and boreholes, the rate of leaking or rainfall index, the depth of boreholes, the nature of soil formation, the frequency of maintenance of the dump-sites and the distance which the waste occupies among others are possible reasons in differences in impact on the quality of groundwater found in dump-site areas. Due to the importance of groundwater as a source of domestic/industrial water supply, farming and other industrial processes, it is important to appraise waste disposal methods in Benin City with a view to guaranteeing continued supplies of clean and safe groundwater. 


\section{REFERENCES}

Abulude, F. O., Obidiram, G. O. and Orungbemi, S. (2007). Determination of Physico-Chemical Parameters and Trace Metal Content of Drinking Waters Samples in Akure, Nigeria. Electronic Journal of Environmental, Agricultural and Food Chemistry, 6(8):2297-2303.

Adeyemo, O. K., Ayodeji I.O, Aiki-Raji C. O. (2002). The Water Quality and Sanitary Condition in a Major Abbatoir (Bodija) in Ibadan, Nigeria. Africa Journal of Biomedical Research. Ibadan Biomedical Communications Group, 1-2: 51-55.

Adeyeye, E. I. and Abulude, (2004). Analytical Assessment of some surface and groundwater resources in IleIfe, Nigeria. Journal of Chemical Society of Nigeria, 29:98-103.

Agbabiaka, T. O. and Sule, I.O. (2010). Bacteriological Assessment of Selected Borehole Water Samples in Ilorin Metropolis. International Journal of Applied Biological Research. 2(2): 31-37.

Ajayi, S. O. and Osibanjo O. (1981). Pollution Studies on Nigerian Rivers II. Water Quality of Some Nigerian Rivers. Environmental Pollution (Ser. B) 2: 87-95.

Alexander, P. (2008): Evaluation of Groundwater Quality of Mubi Town in Adamawa State, Nigeria. African Journal of Biotechnology,7(11):1712 - 1715.

Allen, S. E. (1989). Chemical Analysis of Ecological Materials (pp368-369) Blackwell Scientific Publications.

AOAC (1999). Methods of Analysis Association of Official Analytical Chemists, Washington DC326p.

Awachie, J. B. E. (1981). Running Water Ecology in Africa, In: M.A. Lock and D. D. Willia M.S. (ed) Perspective in Running Water Ecology, Plenum Press, New York and London, pp339 - 366.

Beumer, J. P. (1980). Hydrology and Fish Diversity of a North Queenland Tropical Stream. Australian Journal of Ecology 5:159-186.

Bezuidenhout, C.C., Mthembu, N., Puckree, T., and Lin, J. (2002). Microbiological Evaluation of the Mhlathuze River, Kwazulu-Natal (RSA). Water SA 28:281-286.

Bocco, G. and Silke, C. (2001). Source of Municipal Solid Waste in Developing Countries. Resources, Conservation and Recycling. 32:29-41.

Cheesbrough, M. (2003). District Laboratory Practices in Tropical Countries. Cambridge University Press. United Kingdom. pp. 157-234.

Dauda, A.M. (1993): A Comprehensive Approach in Water Resources Management for the $21^{\text {st }}$ Century, Environmental 1 Bullets vol. 12. Nigeria.

Deutsch, M. (2003). Natural Controls Involved in Shallow Aquifer Contamination. Ground Water 3. U. S. Environmental Protection Agency, pp 37-40.

Duguid, J. P., Marmion B. P. and Swain RHA (1987). Medical Microbiology. Churchill Livingstone Publishers. pp 120 - 200. 
Egborge, A.B.M. (1971). The Chemical Hydrology of the River Oshun, Western State of Nigeria. Freshwater Biology. 1:257-271.

Egborge, A. B. M. and Okoi, E. E. (1987). The Biology of a Community Swamp Farm near Warri, Nigeria. Nigeria Field. 51: (1-2): 2-14.

Ghosh, M. and Singh, S. P. (2005). A Review of Phytoremediation of Heavy Metals and Utilization of it's by Products. Applied Ecology and Environmental Research3 (1): 1-18.

Hall, A. Cvalente, I. M. and Davis, B. R. (1977). The Zambezi River in Mozambique: The Physic-Chemical Status of the Middle and Lower Zambezi Prior to the Closure of the Cabora Bassa Dam. Fresh water biology 7:187-206.

Holden, M. J. and Green, J. (1960). The Hydrology and Plankton of River Sokoto. Journal of Animal Ecology, 29(1):65-842.

Hughes, J. L. (2004). Evaluation of Groundwater Degradation Result from Waste Disposal to Alluvium near Barstow, California. U.S. Geological Survey Professional Paper 878: 211-214

Imevbore, A. M. A. (1970). The Chemistry of the River Niger in the Kainji Reservoir Area. Archeology Hydrobiology 67: 412 - 431.

Nigerian Institute of Safety Professionals (2003). Contractor Employee HSE Training Manual, Level 3, ECNEL Ltd, Port Harcourt, Nigeria.

Ogbeibu, A.E (2005). Biostatistics: A Practical Approach to Research and Data Handling, (1 ${ }^{\text {st }}$ ed. pp55-85) Mindex Publisher, Benin City, Nigeria.

Ogbeibu, A.E., Chukwurah, N.A. and Oboh, I.P. (2013a). Effects of Open Waste Dump-site on its Surrounding Surface Water Quality in Ekurede-Urhobo, Warri, Delta State, Nigeria. Natural Environment 1(1): 1-16

Ogbeibu, A.E., Chukwurah, N.A. and Oboh, I.P. (2013b). Effects of an Open Waste Dump-site on its Surrounding Groundwater in Ekurede-Urhobo, Warri, Delta State, Nigeria. International Journal of Ecology and Environmental Sciences (In Press)

Ogbeibu, A. E. and Victor, R. (1989). The Effect of Road and Bridge Construction on the Bank Root Macroinvertebrates of a Southern Nigeria Stream. Environmental Pollution, 56: 85 - 100.

Olobaniyi, S. B. and Owoyemi, F. B. (2004). Quality of Groundwater in the Deltaic Plain Sand Aquifer of Warri and Environs of Delta State, Nigeria: Water Resource. Journal of the Nig. Assoc. Hydrogeologist, 15, 38-45.

Omofonmwan, S. I. and Esiegbe, J. O. (2009). Effects of Solid Waste on the Quality of Underground Water in Benin Metropolis, Nigeria. Journal of Human Ecology, 26(2):99-105.

Omoigberale, M.O., Ogbeibu A.E. and Olotu, N.O. (2009). Assessment of Groundwater Quality of Benin City, Edo State, Nigeria. Tropical Freshwater Biology, 18(2): 15-35

Purandara, B. K., Varadarajan, N. and Jayasree, K. (2003). Impact of Sewage on Groundwater Quality. A Case 
Study. Pollution Research, 22(2): 189-197.

Raymont, J.E.G. (1983). Plankton and Productivity in the Oceans. I. Phytoplankton and Productivity (pp824-830) Pergamon Press. London.

Schwoerbel, J. (1972). Some Methods of Hydrobiology (Freshwater Biology) (pp21-28). Pergamon Press, Oxford, London.

SSSA (1971). Instrumental Methods for Analysis of Soil and Plant Tissue. (pp27-32) Soil Science Society of America, Corporated, Wisconsin, U.S.A.

Talling, J. F. and J. Rozoska, (1967). The Development of Plankton in Relation to the Hydrobiological Regime in the Blue Niles. Journal Ecology 55:637-662.

Tenore, K. R. (1972). Macrobenthos of Palmico Estuary, North Carolina. Ecology Monographs 42:51-59.

Uhlmann, O. (1979). Hydrobiology. (pp313-316) John Wiley \& Sons. New York.

UNEP (United Nation Environmental Programme) (2002). Vital Water Graphics-An Overview of the State of other World's Fresh \& Marine Water.

Vollenweider, R. A. (1968). Scientific Fundamentals of the Eutrophication of Lakes and Flowing Waters, with Particular Reference to Nitrogen and Phosphorus as Factors in Eutrophication. (pp192-199). Paris Rep. Organization for Economic Co-operation.

Waite, T. D. (1984). Principle of Water Quality. (pp32-38) Academic Press. San Diego.

Wilham, J. L. and Doris T. C. (2005). Biological Parameters for Water Quality Criteria. Bioscience 18(8): 477-481.

Yerima, F. A. K., Daura, M. M., and Gambo, B. A. (2008). Assessment of Groundwater Quality of Bama Town, Nigeria. Journal of Sustainable Development in Agriculture and Environment, 3(2):128-137.

Zhang, M. K., Liu, Z. Y., and Wang, H. (2010). Use of single extraction methods to predict bioavailability of heavy metals in polluted soils to rice. Communications in Soil Science and Plant Analysis. 41(7): 820 831. 